\title{
Ceramic ChemCam Calibration Targets on Mars Science Laboratory
}

\author{
D. Vaniman • M.D. Dyar $\cdot$ R. Wiens $\cdot$ A. Ollila • \\ N. Lanza $\cdot$ J. Lasue $\cdot$ J.M. Rhodes $\cdot$ S. Clegg $\cdot$ \\ H. Newsom
}

Received: 14 October 2011 / Accepted: 13 April 2012 / Published online: 11 May 2012

(C) The Author(s) 2012. This article is published with open access at Springerlink.com

\begin{abstract}
The ChemCam instrument on the Mars Science Laboratory rover Curiosity will use laser-induced breakdown spectroscopy (LIBS) to analyze major and minor element chemistry from sub-millimeter spot sizes, at ranges of $\sim 1.5-7 \mathrm{~m}$. To interpret the emission spectra obtained, ten calibration standards will be carried on the rover deck. Graphite, Ti metal, and four glasses of igneous composition provide primary, homogeneous calibration targets for the laser. Four granular ceramic targets have been added to provide compositions closer to soils and sedimentary materials like those expected at the Gale Crater field site on Mars. Components used in making these ceramics include basalt, evaporite, and phyllosilicate materials that approximate the chemical compositions of detrital and authigenic constituents of clastic and evaporite sediments, including the elevated sulfate contents present in many Mars sediments and soils. Powdered components were sintered at low temperature
\end{abstract}

D. Vaniman $(\bowtie)$

Planetary Science Institute, Tucson, AZ 85719, USA

e-mail: dvaniman@psi.edu

M.D. Dyar

Dept. of Astronomy, Mount Holyoke College, South Hadley, MA 01075, USA

R. Wiens - N. Lanza

Space Remote Sensing, Los Alamos National Laboratory, Los Alamos, NM 87545, USA

A. Ollila $\cdot$ H. Newsom

Institute of Meteoritics, University of New Mexico, Albuquerque, NM 87131, USA

J. Lasue

Observatoire Midi-Pyrénées, Institut de Recherche en Astrophysique et Planétologie, Toulouse, France

J.M. Rhodes

Dept. of Geosciences, University of Massachusetts, Amherst, MA 01003, USA

S. Clegg

Physical Chemistry and Applied Spectroscopy, Los Alamos National Laboratory, Los Alamos,

NM 87545, USA 
$\left(800{ }^{\circ} \mathrm{C}\right)$ with a small amount $(9 \mathrm{wt} . \%)$ of lithium tetraborate flux to produce ceramics that retain volatile sulfur yet are durable enough for the mission. The ceramic targets are more heterogeneous than the pure element and homogenous glass standards but they provide standards with compositions more similar to the sedimentary rocks that will be Curiosity's prime targets at Gale Crater.

Keywords Mars Science Laboratory $\cdot$ ChemCam $\cdot$ Laser induced breakdown spectroscopy $\cdot$ Calibration $\cdot$ Gale Crater $\cdot$ Ceramic $\cdot$ Curiosity

\section{Introduction}

Mars Science Laboratory (MSL) will begin operations on Mars in the summer of 2012. The MSL mission's highly-capable rover (Curiosity) will carry ten instruments, four of which will provide chemical data. First, the Sample Analysis on Mars (SAM) evolved gas and mass spectrometry instrument suite will measure light elements $(\mathrm{C}, \mathrm{H}, \mathrm{O}, \mathrm{N}, \mathrm{S})$ and their compounds from collected powders, and also has the capability for isotopic analysis. Second, the CheMin (Chemistry and Mineralogy) X-ray diffraction and fluorescence instrument will, along with diffraction, provide chemical information for elements heavier than silicon in collected powders. Third, the Alpha Particle X-ray Spectrometer (APXS) will provide full chemical analysis for $\mathrm{Na}$ and heavier elements in contact samples. Finally, the ChemCam (Chemistry Camera) remote analyzer with a Remote Microimager (RMI) will use laserinduced breakdown spectroscopy (LIBS) to analyze major and minor element chemistry from sub-millimeter spot sizes at ranges of $\sim 1.5-7 \mathrm{~m}$. A detailed description of the ChemCam instrument is provided by Wiens et al. (this issue). Each of these instruments will be subject to a calibration and characterization regimen and each will carry standard materials to Mars for use in periodic checks of calibration and performance. In this paper, we describe the preparation and properties of the ceramic targets for ChemCam that will be carried on Curiosity, along with complementary data for the ChemCam shergottite glass standard that is also described in Fabre et al. (2011).

The ChemCam instrument uses laser pulses of $\sim 17 \mathrm{~mJ}$ to generate light-emitting plasma from rocks or regolith for remote elemental analysis of the emission spectra (Wiens et al. this issue; and Maurice et al. this issue). Each laser pulse produces a vaporized spot that varies in scale from $\sim 180 \mu \mathrm{m}$ at $2 \mathrm{~m}$ to $\sim 600 \mu \mathrm{m}$ at $7 \mathrm{~m}$. The range of chemical species measurable by ChemCam covers much of the periodic table up to $\sim Z=92$ (U), including the biologically important elements $\mathrm{H}$ plus $\mathrm{C}, \mathrm{O}, \mathrm{N}, \mathrm{P}, \mathrm{S}$ - with detection limits varying by element. The standoff analytical capability and rapid data acquisition from multiple analysis spots make ChemCam a formidable asset in determining the nature of Curiosity's surroundings and in guiding the rover to the most promising targets for contact analysis.

Included with ChemCam are ten calibration targets, carried in a mount on Curiosity's deck. These targets are located $1.56 \mathrm{~m}$ from the ChemCam laser, which is mounted on top of the rover's mast (ref. Wiens et al. this issue). Two of the targets are pure elements (Ti metal and graphitic $\mathrm{C}$ ), three are synthetic mafic glasses (picrite, norite, and shergottite compositions), one is a natural silicic peraluminous igneous glass ("macusanite" glass from Macusani, Peru), and the remaining four are ceramics. The graphite standard provides calibration of the critical light element $\mathrm{C}$. The glasses provide calibration based on representative basaltic compositions on Mars (picrite, shergottite), an analog of primitive Noachian crust (norite), and for extended calibration a more felsic igneous member (macusanite); the macusanite also contains a small amount of water (up to $0.5 \mathrm{wt} . \% \mathrm{H}_{2} \mathrm{O}$ ). 
Fabre et al. (2011) describe the compositional range, target homogeneity, and application to calibration of the natural and synthetic glasses for major elements $(\mathrm{Si}, \mathrm{Fe}, \mathrm{Al}, \mathrm{Mg}, \mathrm{Ca}$, $\mathrm{O}, \mathrm{Na}$, and $\mathrm{K}$ ) as well as minor and trace elements (Ti, Sr, Cr, Cs, Ba, Li, Zn, Mn, and $\mathrm{Ni}$. The excellent multi-element homogeneity within each of the glasses makes them the primary calibration targets for ChemCam because they have homogeneity well within LIBS analytical precision no matter where the laser beam is placed. However, the glasses represent igneous compositions while the prime targets for Curiosity are sedimentary rocks that may preserve evidence for habitable environments (Grotzinger 2009), as well as soils and sands derived from the sediments. Most important, in light of the expected occurrence of sulfate phases at Gale Crater, the field area that Curiosity will explore, is the need for sulfate-bearing standards.

Exploration of sulfate-rich sediments at Meridiani Planum by the Mars Exploration Rover Opportunity has revealed extensive deposits of sediments with grain sizes typically 0.1-1 mm, with a sulfate component hat includes both sulfate cement and reworked detrital sulfate grains (McLennan et al. 2005; Grotzinger et al. 2006). The sediments of Gale Crater may differ from the cemented sands of Meridiani Planum, but sand-scale granularity and sedimentary porosity are likely to be encountered. Moreover, in addition to sediments it is expected that dune sands and soils with sulfate as well as mafic silicate grains will be found and analyzed by Curiosity. These issues were common to all of the candidate MSL field sites at the time that calibration targets for ChemCam had to be prepared, but of all candidate sites the Gale Crater location has the most extensive and complex sulfate story. It is therefore particularly important that Curiosity have sulfate-bearing calibration targets. The ceramic targets are similar in chemical composition to an evaporite with mafic silicate detritus and clay minerals. As such the ceramics provide a closer chemical approximation of regolith and sediments expected at Gale Crater, although they have inherent heterogeneity due to their granular nature.

Sulfate analysis will be a major goal of MSL, but so too is the analysis of silicate phases derived from aqueous alteration of mafic igneous rocks. The original mission requirements for ChemCam included a desire that LIBS calibration targets have at least one sample representative of each major rock unit expected to be encountered, including basalt, andesite, and a basalt alteration product, as well as a sulfate. The basalt requirement is covered by the basaltic glasses and the macusanite glass provides a compositional member that extends to a silica range beyond andesite. Missing from the homogeneous glass calibration targets are sulfates and alteration products of basalts. However, these components are critical for meeting the mission's objectives to evaluate habitability.

Sulfates and phyllosilicates both occur at Gale Crater (e.g., Milliken et al. 2010). Several clay minerals have been identified on Mars by spectral signatures detected from orbit. Most identifications are of 2:1 smectites or mixed-layer clays, particularly nontronite, saponite, and chlorite as well as 1:1 aluminous phyllosilicates such as kaolinite (Milliken and Bish 2010). Clay minerals provide evidence of past hydrous systems and water is critical to habitability. Similarly, sulfate minerals identified on Mars (principally $\mathrm{Mg}, \mathrm{Ca}$, and Fe sulfates) provide evidence of past hydrous environments. Sulfate phases appear to fill a geochemical role in Mars aqueous surface processes that is assumed by carbonates in the dominant aqueous geochemical cycle on Earth (e.g., McLennan and Grotzinger 2009; King and McLennan 2010). Thus, in addition to providing igneous calibration targets, the ChemCam team created additional ceramic targets that include Mars-like clay minerals (nontronite and kaolinite) as well as a sulfate. All the on-board targets will be used in combination with data acquired with ChemCam before launch, as well as data from Curiosity's other instruments, to examine elemental concentrations in Mars surface materials. 


\subsection{Preparation Methods and Selection of Target Compositions}

Durability is a problem when trying to incorporate a clay mineral or a sulfate phase into a solid analytical target that will be exposed to the martian environment. Clay minerals are soft, and many gain or lose water as humidity changes, swelling or contracting in the process. Studies of smectite hydration at Mars surface conditions indicate that swelling cycles may occur on a daily basis (Bish et al. 2003). Most sulfate minerals are also soft and many occur in varying hydration states that also change with temperature and humidity. For these reasons, calibration targets were created with (1) a clay mineral component that has been processed in a manner (heating to $1000{ }^{\circ} \mathrm{C}$ ) that prevents hydration/dehydration cycling yet preserves the anhydrous chemical composition and (2) a relatively stable sulfate component. Past missions have shown that sediments on Mars incorporate a significant amount of basaltic detritus (e.g., Toulmin et al. 1977; McLennan et al. 2005); therefore we have included a basaltic component in these targets. The clay samples chosen were Fe-rich smectite (nontronite) and an aluminous clay mineral (kaolinite). Most of the ceramics use the nontronite, which is expected at Gale Crater (Milliken et al. 2010), but kaolinite was used in one target to extend compositional range to sediments that include an aluminous clay mineral. The aluminous ceramic composition was selected in part for the candidate MSL site at Mawrth Vallis, where abundant aluminous clay minerals are identified from orbit, but such compositions might occur at all of the original candidate sites and the added range in composition is useful for calibration in general.

To prepare a durable sulfate phase, we synthesized anhydrite, chosen for its relative thermal stability and lack of water of hydration. Most other sulfate minerals hydrate and can change hydration state readily. Arcanite, $\mathrm{K}_{2} \mathrm{SO}_{4}$, is one of the few sulfates that is a stable non-hydrate and was also considered but potassium is not abundant on the martian surface and anhydrite is more representative of Ca-sulfates that Curiosity might encounter on Mars (e.g., Clark et al. 2005). For the basaltic component, we used a specimen from Totavi, NM, USA, that has been analyzed many times as an internal standard for X-ray fluorescence analyses at Los Alamos National Laboratory (LANL).

Figure 1a is a ternary diagram showing the as-mixed weight proportions of basalt, anhydrite, and processed clay minerals (heated to $1000{ }^{\circ} \mathrm{C}$ ) in the ceramic targets. In describing the ceramics throughout this paper the terms "low S", "mid S", and "high S" are used as shown in this figure. Figure $1 \mathrm{~b}$ shows discs of the ceramics after firing. The ceramic compositions and mixing proportions are detailed in Table 1. In concept, these targets mimic potential sediments or regolith on Mars that contain detrital basaltic sands along with either detrital or authigenic phyllosilicates and salts. As noted above, sedimentary mixtures of detrital basalt with reworked and reprecipitated sulfate minerals have been proposed for some of the best exposed sediments at the MER Opportunity site on Meridiani Planum (McLennan et al. 2005). Whether clay minerals are also present in those sediments is not known. However, observations from orbit suggest both clay minerals and sulfates occur interstratified, and potentially in intimate association, within the sedimentary sequence at Gale Crater (Milliken et al. 2010). The goal of ceramic target preparation was to represent the chemical makeup of such assemblages in a form durable enough to survive as analytical targets on Curiosity. Durability with the best possible homogeneity and finest possible grain size was desired. Meeting these goals required testing of possible preparation methods prior to target fabrication. 
Fig. 1 (a) Ternary view of weight-percent ceramic target compositions for ChemCam based on sulfate, phyllosilicate, and basalt constituents expected to be common at Gale Crater. (b) Photographs of the four as-fired ceramic targets

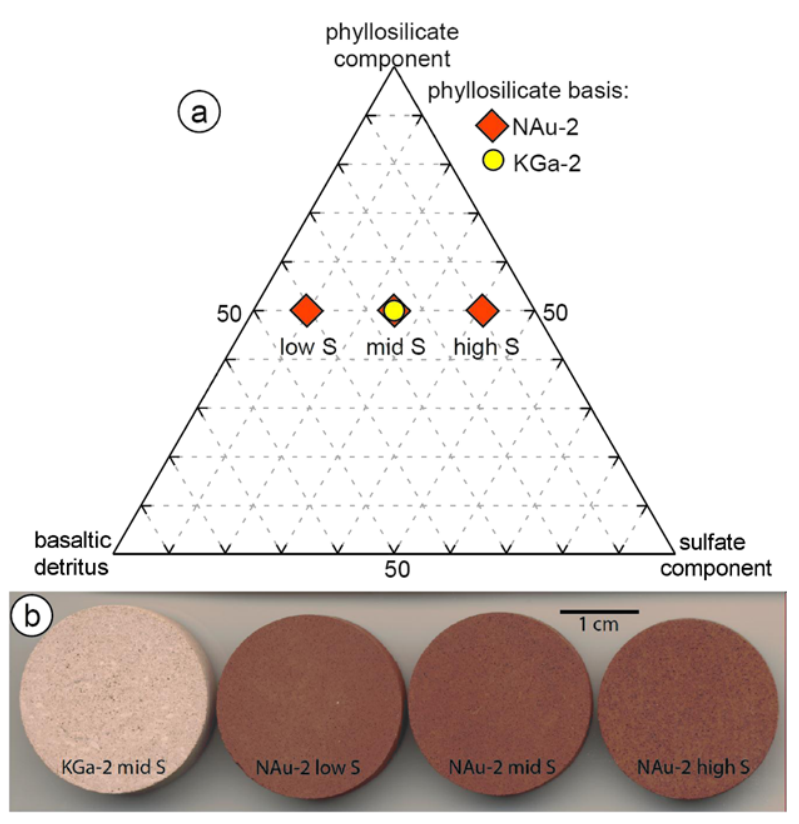

\subsection{Ceramic Synthesis Tests and Fabrication}

The anhydrite used in fabricating ceramic targets was prepared from Mallinckrodt ${ }^{\circledR}$ reagent $\mathrm{CaSO}_{4} \cdot 2 \mathrm{H}_{2} \mathrm{O}$ by stepwise heating to $800{ }^{\circ} \mathrm{C}$ over $6 \mathrm{~h}$ with a hold at $800{ }^{\circ} \mathrm{C}$ for $2.5 \mathrm{~h}$. The product was confirmed by XRD to have an anhydrite structure. The anhydrite produced at this temperature was tested by exposure for a year at $100 \% \mathrm{RH}$ and room temperature; no rehydration was observed at these conditions. Reagent $\mathrm{CaSO}_{4} \cdot 2 \mathrm{H}_{2} \mathrm{O}$ heated at lower temperatures also produced anhydrite structures but could rehydrate at room conditions (e.g., 'soluble anhydrite' as described in Christensen et al. 2008). The higher-temperature anhydrite was used in order to minimize weight changes in the ceramics during fabrication; the anhydrite component of the ceramics has a similar heating and cooling profile and should be stable during flight and on Mars.

The basaltic component used in the ceramic targets was collected from exposures of a 2.3 Ma lava flow above Totavi, New Mexico, USA. The Totavi basalt is an olivine-phyric tholeiitic basalt that was collected, crushed, and powdered in large quantity for use as an internal standard in the Geology and Geochemistry X-ray fluorescence (XRF) Laboratory at LANL. Splits of this powder have been analyzed more than 200 times over the past 25 years; the average analysis is shown in Table 1 . The composition of this powder is well constrained and the variability for all major elements between repeat analyses is within $\pm 2 \%$ relative of the value listed.

The clay mineral components of the ceramics were reference samples obtained from the Clay Minerals Society. Emphasis was on Fe-rich clay minerals, which appear to be among the most common clay minerals on Mars. Australian nontronite NAu-2 from the Uley graphite mine in southern Australia was selected for this reason. Three of the ceramics were made with this nontronite (Fig. 1a, b). The fourth ceramic contains kaolinite KGa2 from Warren County, Georgia, USA, to support analysis of martian samples containing a highly aluminous clay mineral. Note that these clay minerals are not completely pure but the minor contributions from other phases are evenly distributed. NAu-2 contains submicron 
Table 1 Components used in syntheses

\begin{tabular}{|c|c|c|c|c|c|c|c|}
\hline & $\begin{array}{l}\text { Raw Clay } \\
\text { NAu-2 }\end{array}$ & $\begin{array}{l}1000{ }^{\circ} \mathrm{C} \\
\text { fired } \\
\text { NAu-2 }\end{array}$ & $\begin{array}{l}\text { Raw Clay } \\
\text { KGa-2 }\end{array}$ & $\begin{array}{l}1000^{\circ} \mathrm{C} \\
\text { fired } \\
\mathrm{KGa}-2\end{array}$ & $\begin{array}{l}\text { Totavi } \\
\text { basalt }\end{array}$ & Anhydrite & $\begin{array}{l}\mathrm{Li} \\
\text { Tetra- } \\
\text { borate }\end{array}$ \\
\hline Analysis method & ICP & $\mathrm{XRF}$ & ICP & XRF & $\mathrm{XRF}$ & Reagent & Reagent \\
\hline $\mathrm{SiO}_{2}$ & 48.70 & 55.50 & 44.50 & 52.65 & 50.66 & - & - \\
\hline $\mathrm{Al}_{2} \mathrm{O}_{3}$ & 4.53 & 5.36 & 36.81 & 44.39 & 15.55 & - & - \\
\hline $\mathrm{TiO}_{2}$ & 0.595 & 0.724 & 2.182 & 2.496 & 1.42 & - & - \\
\hline $\mathrm{Fe}_{2} \mathrm{O}_{3}(\mathrm{~T})$ & 31.76 & 33.42 & 0.82 & 0.92 & 11.54 & - & - \\
\hline $\mathrm{MnO}$ & 0.016 & 0.02 & 0.00 & 0.01 & 0.16 & - & - \\
\hline $\mathrm{MgO}$ & 0.77 & 0.88 & 0.04 & 0.05 & 7.30 & - & - \\
\hline $\mathrm{CaO}$ & 1.96 & 2.39 & 0.02 & 0.09 & 8.82 & 41.19 & - \\
\hline $\mathrm{Na}_{2} \mathrm{O}$ & 0.70 & 0.78 & 0.02 & 0.04 & 3.14 & - & - \\
\hline $\mathrm{K}_{2} \mathrm{O}$ & 0.13 & 0.17 & 0.07 & 0.10 & 0.97 & - & - \\
\hline $\mathrm{P}_{2} \mathrm{O}_{5}$ & 0.08 & 0.10 & 0.06 & 0.08 & 0.30 & - & - \\
\hline $\mathrm{SO}_{3}$ & - & - & - & - & - & 58.81 & - \\
\hline $\mathrm{Li}_{2} \mathrm{O}$ & - & - & - & - & - & - & 82.33 \\
\hline $\mathrm{B}_{2} \mathrm{O}_{3}$ & - & - & - & - & - & - & 17.67 \\
\hline LOI & 11.69 & - & 14.63 & - & - & - & - \\
\hline Total & 100.93 & 99.35 & 99.15 & 100.80 & 99.86 & 100.00 & 100.00 \\
\hline \multicolumn{8}{|c|}{ Weight percentages used in ceramics } \\
\hline & \multicolumn{2}{|c|}{$\begin{array}{l}\text { Dehydrated } \\
\text { NAu-2 }\end{array}$} & $\begin{array}{l}\text { Dehydrated } \\
\text { KGa-2 }\end{array}$ & $\begin{array}{l}\text { Totavi } \\
\text { basalt }\end{array}$ & \multicolumn{2}{|r|}{ Anhydrite } & $\begin{array}{l}\mathrm{Li} \\
\text { Tetraborate }\end{array}$ \\
\hline NAu-2 low $\mathrm{S}$ & \multicolumn{2}{|l|}{45.50} & & 35.50 & \multicolumn{2}{|r|}{10.00} & 9.00 \\
\hline $\mathrm{NAu}-2$ mid $\mathrm{S}$ & \multicolumn{2}{|l|}{45.50} & & 22.75 & \multicolumn{2}{|r|}{22.75} & 9.00 \\
\hline NAu-2 high $S$ & \multicolumn{2}{|c|}{45.50} & & 10.00 & \multicolumn{2}{|r|}{35.50} & 9.00 \\
\hline $\mathrm{KGa}-2$ mid $\mathrm{S}$ & & & 45.50 & 22.75 & \multicolumn{2}{|r|}{22.75} & 9.00 \\
\hline
\end{tabular}

Raw clay analyses are as-received from the Clay Minerals Society and include some mineral impurities in addition to the clay mineral (Fig. 5); $1000{ }^{\circ} \mathrm{C}$ fired clays represent the same material pre-fired (prior to ceramic formulation) to prevent hydration while processing ceramics. Compositions by ICP are from Actlabs; compositions by XRF were obtained at University of Massachusetts with the exception of the Totavi basalt, which is a LANL reference material. Reagent compositions $\left(\mathrm{CaSO}_{4}\right.$ as anhydrite and lithium tetraborate) are as-certified

carbonate and iron oxyhydroxide (Keeling et al. 2000) while $\mathrm{KGa}-2$ has been reported to have $3 \%$ anatase, $1 \%$ crandallite, and traces of mica and/or illite (Chipera and Bish 2001). Our XRD analysis of the as-received NAu-2 sample shows presence of a trace amount of feldspar; anatase is present in the as-received KGa-2 (Fig. 2) but we did not detect crandallite or mica/illite.

Low-temperature preparation of grain mixtures in a binder was considered but faced problems because the most promising binders were organic compounds incompatible with MSL requirements; in addition, the ratio of binder to grains necessary for durability seemed excessive. Consideration was then given to firing the ceramics at a temperature low enough $\left(\leq 800{ }^{\circ} \mathrm{C}\right)$ that sulfur in the sulfate mineral component would not be released. However, common clay-based ceramics are generally fired to much higher temperatures. "High-fire" 

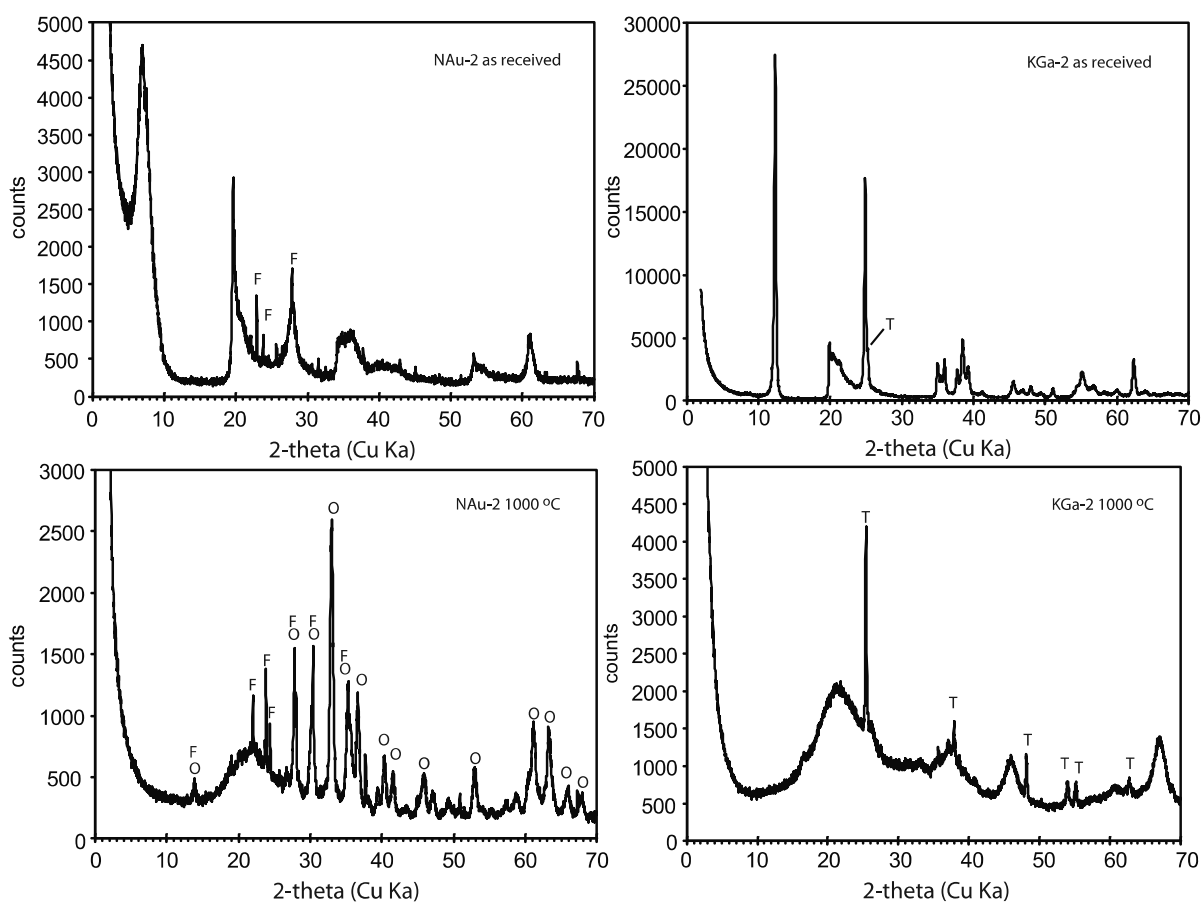

Fig. 2 X-ray diffraction analyses of as-received Clay Minerals Society source nontronite NAu-2 and kaolinite $\mathrm{KGa}-2$, compared with analyses of the products obtained after pre-firing to $1000{ }^{\circ} \mathrm{C}$. Phase symbols are $\mathrm{F}=$ feldspar, $\mathrm{O}=$ orthorhombic $\mathrm{Fe}_{2} \mathrm{O}_{3}\left(\varepsilon-\mathrm{Fe}_{2} \mathrm{O}_{3}\right)$, and $\mathrm{T}=\mathrm{TiO}_{2}$ (anatase). All data were collected at the same conditions and variation in the scale of the vertical axis is sample-dependent

ceramics are fired to peak temperatures of $\sim 1300{ }^{\circ} \mathrm{C}$ ("cone $10^{\prime}$ " to a potter), and even ceramics considered "low-fire" are fired to $\sim 1000{ }^{\circ} \mathrm{C}$ ("cone 06 " to a potter). Trials were performed with firing of both dry and slurry mixtures of several different Clay Minerals Society source clays, including ferruginous smectite SWa-1 from Grant County, Washington, USA, and sodium montmorillonite SWy-1 from Crook County, Wyoming, USA, as well as the nontronite NAu-2 and kaolinite KGa-2 ultimately used in making the ceramic targets. These source clays were mixed with powdered anhydrite and Totavi basalt in variable ratios and fired to $800{ }^{\circ} \mathrm{C}$. However, all of the fired products were powdery, friable, and extremely weak. Examination showed that even after firing to $800^{\circ} \mathrm{C}$ the clay mineral components retained the ability to expand and contract with changes in humidity, making the test samples unstable. At this point, it was decided to pre-fire the clay-mineral component at $1000{ }^{\circ} \mathrm{C}$. This practice is used routinely at LANL (e.g., Vaniman et al. 2002) for analysis of clay minerals by XRF, in order to maintain accurate sample weights in fused-disc preparation. Heating at $1000{ }^{\circ} \mathrm{C}$ destroys the clay-minerals' crystalline structure and thereby their ability to rehydrate. Pre-firing at this temperature does not result in significant loss of volatile components other than water and hydroxyl. The pre-fired kaolinite and nontronite lost all clay mineral structure and became mixtures of $\mathrm{X}$-ray amorphous material plus either anatase in $\mathrm{KGa}-2$ or $\varepsilon-\mathrm{Fe}_{2} \mathrm{O}_{3}$ (orthorhombic $\mathrm{Fe}_{2} \mathrm{O}_{3}$ ) and feldspar in NAu-2 (Fig. 2).

With pre-fired clay minerals it was necessary to supplement the fired clay, basalt, and anhydrite mixtures with a flux to allow the mixture to sinter at $800{ }^{\circ} \mathrm{C}$. A common potter's method for promoting sintering or melting of clay bodies and glazes is to add a borate, 
such as commercial "Gerstley Borate" obtained from mines near Death Valley, California, USA. Such commercial materials are complex mixtures (e.g., Gerstley Borate is a mixture of colemanite, ulexite, and hectorite plus minor contaminants). To maintain better control of our composition, we tested additions of chemically pure lithium tetraborate $\left(\mathrm{Li}_{2} \mathrm{~B}_{4} \mathrm{O}_{7}\right)$ that is used routinely in higher amounts (e.g., $\sim 10$ times sample powder) to make fused discs for XRF analysis of rock powders. Varying amounts of lithium tetraborate were mixed with powders of the Totavi basalt, anhydrite, and several pre-fired source clays (SWa-1, NAu-2, and $\mathrm{KGa}-2$ ) and fired to $800{ }^{\circ} \mathrm{C}$. Results of these tests indicated that in samples with a $\mathrm{Li}_{2} \mathrm{~B}_{4} \mathrm{O}_{7}$ content of $15 \%$, numerous microcracks appeared on cooling; samples with $20 \%$ flux and higher were weakened by extensive glass formation. Vesiculation became more extensive as the addition of flux increased and at flux concentrations $>50 \%$, immiscible bodies of anhydrite up to $\sim 2 \mathrm{~mm}$ in diameter formed. However, at flux concentrations between $5-10 \%$ by weight, ceramics were formed of moderate grain size $(<100 \mu \mathrm{m})$ with minimal vesiculation ( $<30 \%$ vesicles of $\sim 100-200 \mu \mathrm{m}$ or less). The flux concentrations near $5 \%$ produced softer ceramics, readily scratched by a steel probe, whereas flux concentrations near 9-10\% produced the hardest nontronite-based ceramics. Kaolinite-based ceramics were softer than the smectite-based ceramics. As a result of these tests, it was determined that all of the ceramic mixtures would be fired with 9 wt. $\% \mathrm{Li}_{2} \mathrm{~B}_{4} \mathrm{O}_{7}$ flux.

The Totavi basalt powder, pre-fired nontronite, and pre-fired kaolinite were each ground in a W-carbide shatterbox before mixing with other components. The prepared anhydrite was hand-ground in an agate mortar before mixing. Lithium tetraborate that was added to the mixture was available as a finely-powdered product from SPEX ${ }^{\circledR}$ and required no pregrinding before mixing. Each of the four ceramic formulations was prepared as a carefullyweighed $50 \mathrm{~g}$ single batch. All four-component mixtures (basalt, anhydrite, pre-fired clay mineral, and Li-tetraborate) were first mixed by hand and then ground in a W-carbide shatterbox twice, first for $45 \mathrm{~min}$ and then remixed by hand and re-ground in the shatterbox for another $20 \mathrm{~min}$. Microscope analysis of grains in oil showed that the powders produced are mostly $5-15 \mu \mathrm{m}$, although rare $(<1 \%)$ grains of basalt up to $75 \mu \mathrm{m}$ remain.

The mixed powders for each ceramic were dry pressed at $7 \times 10^{3} \mathrm{~kg}$ for seven min to create cohesive samples for firing. A special die of sleeve, piston, and platens was machined from tool steel to produce pressed powders of the right diameter $(23 \mathrm{~mm})$ to fit the $22 \pm$ $0.5 \mathrm{~mm}$ ChemCam standard holder on the Curiosity rover deck. The press piston diameter of $23 \mathrm{~mm}$ allowed for $3.8 \%$ to $4.8 \%$ shrinkage after firing (as determined from test samples), with greatest shrinkage in compositions of higher sulfur content. Initial attempts at pressing each disc individually to a thickness of $\sim 4-5 \mathrm{~mm}$ to fit the ChemCam standard holder failed. At this thickness, the pressed powders had a persistent tendency to spall as soon as pressure was released. After multiple failures, it was found that spallation could be eliminated by pressing a larger sample, 11 to $13 \mathrm{~mm}$ thick, and cutting two discs of the required thickness from each of the taller cylinders after firing.

Weights of the pressed powder cylinders were $\sim 10 \mathrm{~g}$; the kaolinite cylinders were tallest in order to attain this weight. Each pressed cylinder was fired in the same manner, following the heating and cooling cycle shown in Fig. 3. To minimize loss of structural integrity, the pressed samples were heated in temperature increments of no more than $100{ }^{\circ} \mathrm{C}$ before being held at $800{ }^{\circ} \mathrm{C}$ for one hour. Firing and cooling were accomplished under ambient atmosphere and the samples were allowed to cool ballistically in the furnace; cooling times to $<100{ }^{\circ} \mathrm{C}$ were $\sim 8 \mathrm{hrs}$. Weight losses on firing were $\sim 0.4 \%$ for all of the ceramics except the NAu-2 low $\mathrm{S}$ composition, which had a weight loss of $\sim 0.3 \%$.

As noted above, shrinkage of the ceramics on firing varied with composition. All of the pressed-powder cylinders were $23 \mathrm{~mm}$ in diameter. Diameters of the ceramic products 
Fig. 3 Oven temperature record of firing cycle for ChemCam ceramic targets. Note drying period of 14 hours at $90^{\circ} \mathrm{C}$ before rise to $105^{\circ} \mathrm{C}$ for an hour and ramp to $800{ }^{\circ} \mathrm{C}$ with one hour holds at 150, 200, 300, 400, $500,600,700$, and $800{ }^{\circ} \mathrm{C}$

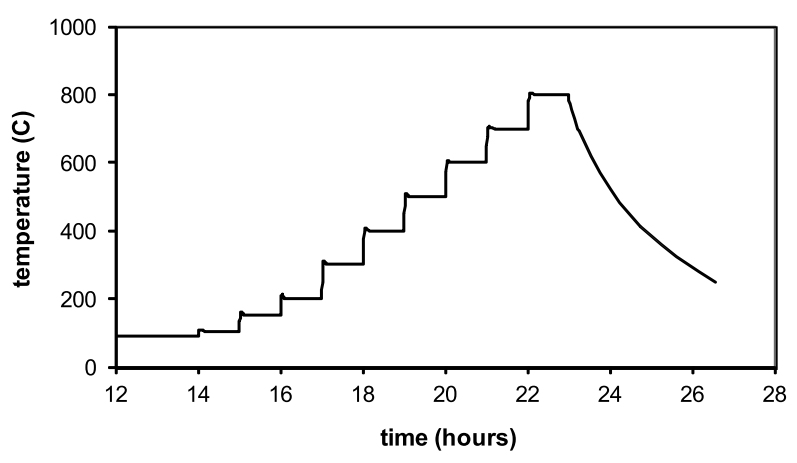

ranged from $22.5 \mathrm{~mm}$ in the $\mathrm{KGa}-2 \mathrm{mid} \mathrm{S}$ composition to $22.0 \mathrm{~mm}$ (NAu-2 low $\mathrm{S}$ ), $21.9 \mathrm{~mm}$ (NAu-2 mid S), and $21.6 \mathrm{~mm}$ (NAu-2 high S). Bulk densities of the ceramics are greatest in the NAu-2 compositions $\left(2.27-2.42 \mathrm{~g} / \mathrm{cm}^{3}\right)$ and significantly lower in the $\mathrm{KGa}-2$ ceramic $\left(1.75 \mathrm{~g} / \mathrm{cm}^{3}\right)$, as expected based on the much lower density of kaolinite relative to nontronite. However, among the nontronite-based ceramics, density decreased as the ratio of basaltic powder to Ca-sulfate increased, despite the greater grain density of basalt. This is attributed to greater shrinkage and compaction with higher sulfur content.

After firing, discs of 4-5 mm thickness were cut from the 11-13 mm tall ceramic cylinders using a thin diamond blade in an Isomet ${ }^{\circledR}$ saw. High-purity ethanol was used as a cooling fluid (rather than water) during cutting. Remnants after cutting two 4-5 mm thick discs were used to make thin sections for optical and microbeam analysis. Some uncut cylinders were used for XRF and ICP/IR analysis. All powder collected during cutting was reserved and used for XRD analysis, although it was eventually found that some of the anhydrite in powder collected from the saw had hydrated to gypsum despite the use of ethanol in cutting. This is likely a result of ethanol hydration. For this reason, representative discs of the finished ceramics were eventually sacrificed for powder XRD analysis.

\section{Analytical Methods}

\subsection{Powder X-Ray Diffraction (XRD)}

Powder X-ray diffraction data were obtained with a Siemens D500 diffractometer using $\mathrm{Cu} \mathrm{K} \alpha$ radiation, incident- and diffracted-beam Soller slits, and a Kevex $\mathrm{Si}(\mathrm{Li})$ solid-state detector, measuring from $2^{\circ}$ to $70^{\circ} 2 \theta$. Powdered samples were analyzed in front-packed glass sample holders with cavities large enough to completely contain the X-ray beam. XRD analyses were obtained for the NAu- 2 and $\mathrm{KGa}-2$ bulk samples as received from the Clay Minerals Society, for the material obtained by pre-firing these at $1000{ }^{\circ} \mathrm{C}$, for the Totavi basalt, and for all four of the ceramic compositions after firing. Diffraction patterns were analyzed with $\mathrm{JADE}^{\circledR}$ software from Materials Data Incorporated.

\subsection{X-Ray Fluorescence (XRF)}

The Totavi basalt XRF measurements given in Table 1 were made at LANL. All the other XRF data in Tables 1 and 2 were measured in the XRF lab at the University of Massachusetts using standard operating procedures (Rhodes 1996; Rhodes and Vollinger 2004). For the $\mathrm{XRF}$ analysis of major elements, samples were prepared as fused La-bearing lithium borate 
glass discs using the methods of Norrish and Hutton (1969), though each sample was first ignited at $1040{ }^{\circ} \mathrm{C}$ for several hours in order to oxidize the iron to $\mathrm{Fe}^{3+}$ and remove volatiles. All elements (including Na) were measured simultaneously using a Siemens MRS-400 spectrometer. Estimates of accuracy and precision are given in Rhodes (1996) and 1- $\sigma$ errors are presented in the footnote to Table 2. Sulfur was measured on a Panalytical 2400 sequential $\mathrm{X}$-Ray spectrometer on a separate glass disc that was fused with an excess of lithium nitrate to ensure oxidation and retention of the sulfur as sulfate.

\subsection{Instrumental Neutron Activation Analyses (INAA)}

Some trace and minor elements (Table 3) were analyzed using INAA at Actlabs in Ancaster, Ontario. For that procedure, $1 \mathrm{~g}$ aliquots were analyzed along with internal standards at a thermal neutron flux of $7 \times 10^{12} \mathrm{n} \mathrm{cm}^{-2} \mathrm{~s}^{-1}$ and counted with a high-purity Ge detector. Results were calibrated against certified international reference materials. Several samples were reanalyzed to check the results. Detection limits are given in Table 3.

Chlorine was also analyzed by INAA following the same irradiation sequence noted above, after $\mathrm{Al}$ and other very short-life isotopes had decayed. The detection limit for $\mathrm{Cl}$ is $0.01 \%$; measured $\mathrm{Cl}$ in all samples was below this value except for sample $\mathrm{KGa}-2$, which contained $0.03 \% \mathrm{Cl}$.

\subsection{Boron Analysis by Prompt Gamma Neutron Activation (PGNAA)}

For PGNAA analysis of boron, $1 \mathrm{~g}$ samples in polyethylene vials were exposed at Actlabs to thermalized neutrons and the Doppler-broadened prompt gamma peak at $478 \mathrm{KeV}$ was measured. Certified reference materials were used for calibration. Detection limits of the method are better than $1 \mathrm{ppm}$ but the recommended upper limit for the method is $\sim 1 \%$, somewhat lower than the $2.3 \%$ boron expected in the ceramics. The PGNAA results for boron as borate are reported in Table 2 but are not used in representing the preferred composition because the reported values fall outside the recommended range of the method.

\subsection{Infrared Analyses (IR)}

For IR analysis of $\mathrm{C}$ and $\mathrm{S}$ at Actlabs, accelerator material was added to a $0.2 \mathrm{~g}$ sample to couple with the high frequency field of the induction furnace in a pure oxygen environment. During combustion, carbon-bearing components reacted to produce $\mathrm{CO}_{2}$ and a lesser amount of CO. Sulfate reacted to form $\mathrm{SO}_{2}$ and sulfur was measured as $\mathrm{SO}_{2}$ in an IR cell. For this procedure, results are reported as "IR" in Table 2.

The small amount of $\mathrm{CO}$ was oxidized to $\mathrm{CO}_{2}$ in a catalytic heater and total $\mathrm{CO}_{2}$ was measured in an IR cell; energy from the IR source was absorbed as the gas passed through the cell and all other IR energy was prevented from reaching the IR detector by a narrow bandpass filter. Absorption of IR energy can thus be attributed only to $\mathrm{CO}_{2}$. An Eltra CS2000 detector was used for the analysis. Detection limits for $\mathrm{C}$ and $\mathrm{S}$ in this process are $0.01 \%$. Measured $\mathrm{C}$ values for all samples were very close to this detection limit $0.04 \%$ for shergottite, NAu-2 low S, NAu-2 high S, and NAu-2 mid-S; $0.06 \%$ for KGa-2 mid-S and for raw clay sample of $\mathrm{KGa}-2$; and $0.03 \%$ for the raw clay sample of $\mathrm{NAu}-2$ ) and therefore are not reported in Table 2.

Sulfur was also analyzed at Actlabs using the "Leco method," which yields $\mathrm{SO}_{2}$ analyses that are recalculated as $\mathrm{SO}_{3}$ for tabulation ("Leco IR" in Table 2) with detection limits of $0.3 \%$. In this procedure a $0.2 \mathrm{~g}$ sample was combusted at $550{ }^{\circ} \mathrm{C}$ in pure oxygen. Sulfur-bearing components release $\mathrm{S}$ that is oxidized to $\mathrm{SO}_{2}$ in the oxygen environment and measured as such in an infrared cell. 


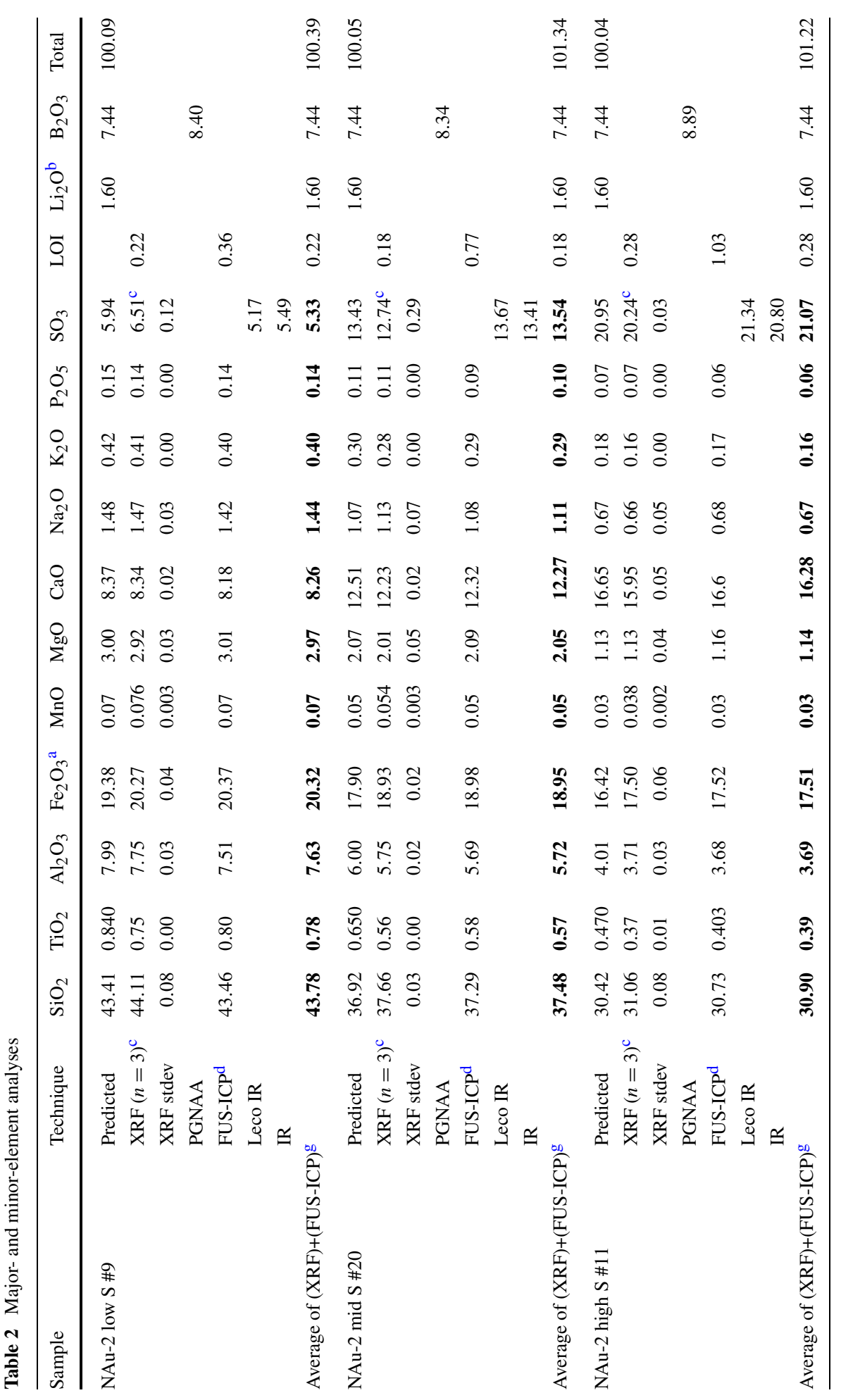




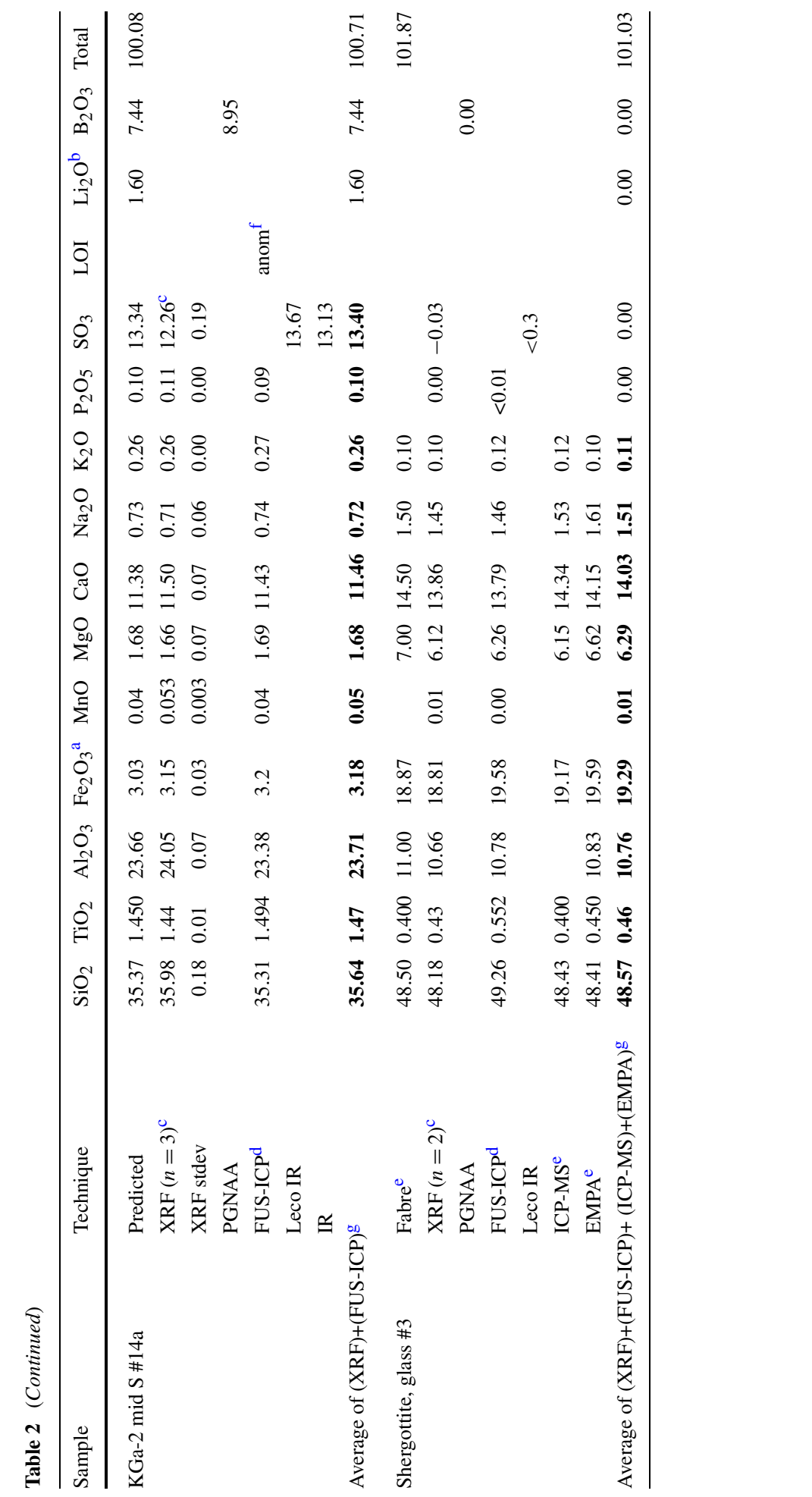




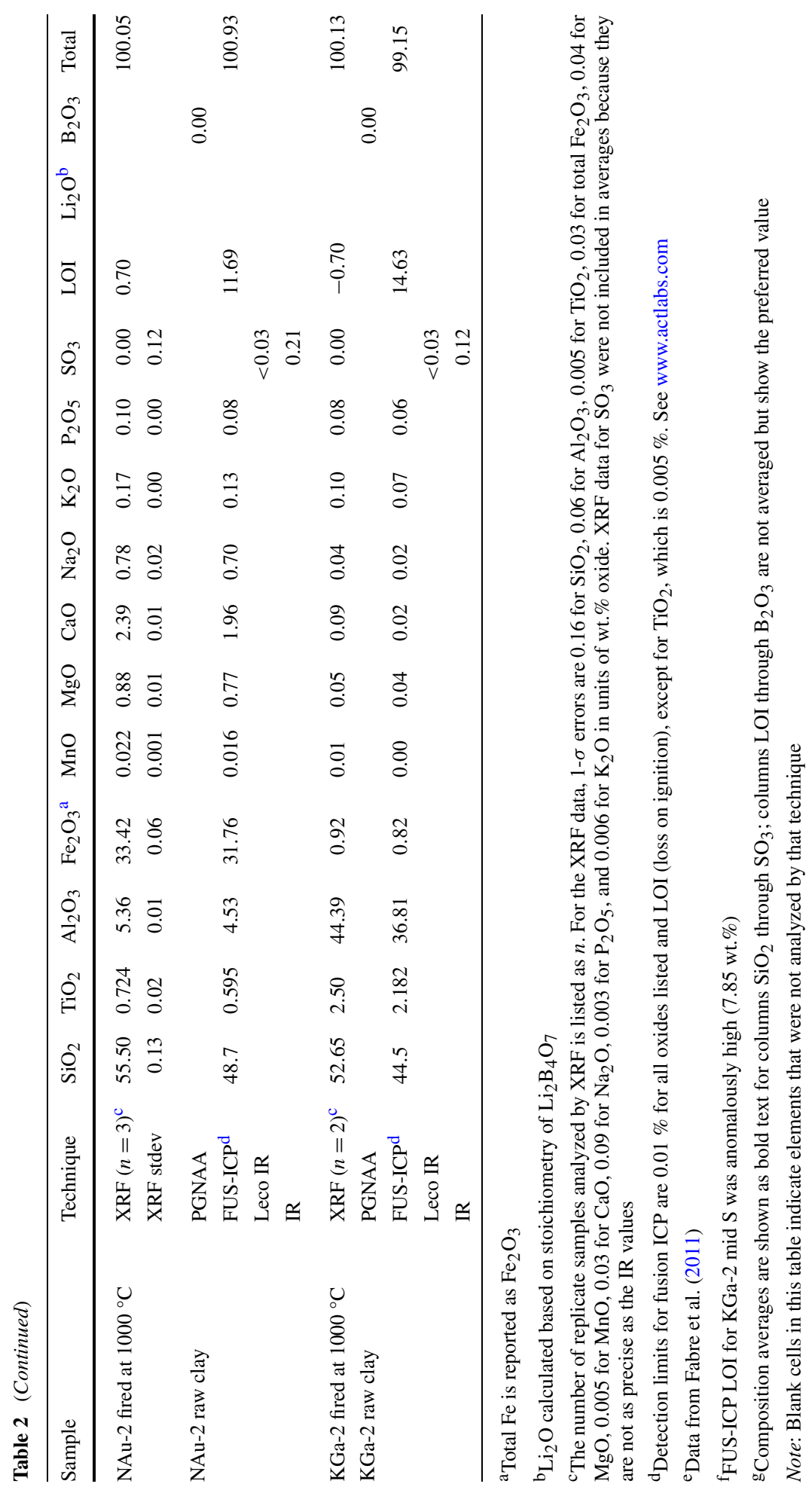


Table 3 Trace-element data for finished ceramics and raw clay samples

\begin{tabular}{|c|c|c|c|c|c|c|c|c|c|}
\hline Analyte & Unit & D.L. & Method & $\begin{array}{l}\text { NAu-2 } \\
\text { low S }\end{array}$ & $\begin{array}{l}\text { NAu-2 } \\
\text { mid S }\end{array}$ & $\begin{array}{l}\text { NAu-2 } \\
\text { high S }\end{array}$ & $\begin{array}{l}\mathrm{KGa}-2 \\
\text { mid S }\end{array}$ & $\begin{array}{l}\text { NAu-2 } \\
\text { raw }\end{array}$ & $\begin{array}{l}\text { KGa-2 } \\
\text { raw }\end{array}$ \\
\hline $\mathrm{Ag}$ & $\mathrm{ppm}$ & 0.5 & ICP-MS & 0.6 & $<0.5$ & $<0.5$ & $<0.5$ & $<0.5$ & 0.8 \\
\hline As & $\mathrm{ppm}$ & 0.5 & INAA & $<0.5$ & $<0.5$ & $<0.5$ & 2.9 & $<0.5$ & $<0.5$ \\
\hline As & ppm & 5 & ICP-MS & $<5$ & $<5$ & $<5$ & $<5$ & $<5$ & $<5$ \\
\hline As & \multicolumn{3}{|c|}{ recommended } & $<0.5$ & $<0.5$ & $<0.5$ & 2.9 & $<0.5$ & $<0.5$ \\
\hline $\mathrm{Au}$ & $\mathrm{ppb}$ & 2 & INAA & 92 & 8 & 32 & 68 & $<2$ & $<2$ \\
\hline $\mathrm{Ba}$ & ppm & 3 & FUS-ICP & 162 & 107 & 56 & 140 & 46 & 83 \\
\hline $\mathrm{Be}$ & ppm & 1 & FUS-ICP & $<1$ & $<1$ & $<1$ & 1 & 1 & 2 \\
\hline $\mathrm{Bi}$ & ppm & 0.1 & ICP-MS & $<0.1$ & $<0.1$ & $<0.1$ & 0.3 & $<0.1$ & 0.7 \\
\hline $\mathrm{Br}$ & ppm & 0.5 & INAA & $<0.5$ & $<0.5$ & 2.2 & $<0.5$ & $<0.5$ & $<0.5$ \\
\hline $\mathrm{Ce}$ & ppm & 0.05 & ICP-MS & 73.6 & 16.3 & 13.7 & 77.7 & 8.58 & 139 \\
\hline $\mathrm{Co}$ & ppm & 1 & ICP-MS & 48 & 35 & 19 & 37 & 13 & 5 \\
\hline $\mathrm{Cr}$ & ppm & 5 & INAA & 81 & 57 & 37 & 61 & 55 & 74 \\
\hline $\mathrm{Cr}$ & $\mathrm{ppm}$ & 20 & ICP-MS & 120 & 80 & 50 & 90 & 40 & 40 \\
\hline $\mathrm{Cr}$ & \multicolumn{3}{|c|}{ recommended } & 81 & 57 & 37 & 61 & 55 & 74 \\
\hline Cs & ppm & 0.1 & ICP-MS & 0.2 & 0.2 & 0.1 & 0.2 & 0.1 & $<0.1$ \\
\hline $\mathrm{Cu}$ & ppm & 10 & ICP-MS & 30 & 20 & 10 & 30 & $<10$ & $<10$ \\
\hline Dy & ppm & 0.01 & ICP-MS & 2.81 & 1.68 & 1.22 & 3.43 & 0.95 & 4.34 \\
\hline $\mathrm{Er}$ & ppm & 0.01 & ICP-MS & 1.61 & 0.93 & 0.68 & 1.74 & 0.54 & 2.02 \\
\hline $\mathrm{Eu}$ & ppm & 0.005 & ICP-MS & 0.842 & 0.512 & 0.331 & 1.14 & 0.376 & 1.6 \\
\hline $\mathrm{Ga}$ & ppm & 1 & ICP-MS & 10 & 7 & 5 & 40 & 4 & 56 \\
\hline Gd & ppm & 0.01 & ICP-MS & 2.84 & 1.61 & 1.11 & 3.86 & 1.01 & 5.37 \\
\hline $\mathrm{Ge}$ & ppm & 0.5 & ICP-MS & 0.7 & $<0.5$ & $<0.5$ & 2.2 & $<0.5$ & 2.8 \\
\hline Hf & ppm & 0.1 & ICP-MS & 1.5 & 1 & 0.7 & 4.3 & 1 & 5.8 \\
\hline Ho & ppm & 0.01 & ICP-MS & 0.55 & 0.33 & 0.24 & 0.65 & 0.19 & 0.77 \\
\hline In & ppm & 0.1 & ICP-MS & $<0.1$ & $<0.1$ & $<0.1$ & $<0.1$ & $<0.1$ & $<0.1$ \\
\hline $\mathrm{Ir}$ & $\mathrm{ppb}$ & 5 & INAA & $<5$ & $<5$ & $<5$ & $<5$ & $<5$ & $<5$ \\
\hline $\mathrm{La}$ & ppm & 0.05 & ICP-MS & 47.8 & 8.93 & 6.45 & 46.3 & 4.46 & 83.9 \\
\hline $\mathrm{Lu}$ & ppm & 0.002 & ICP-MS & 0.229 & 0.147 & 0.126 & 0.248 & 0.117 & 0.277 \\
\hline Mo & ppm & 2 & ICP-MS & $<2$ & $<2$ & $<2$ & $<2$ & $<2$ & 3 \\
\hline $\mathrm{Nb}$ & ppm & 0.2 & ICP-MS & 39.1 & 12.7 & 15.6 & 35.1 & 5.9 & 49.8 \\
\hline $\mathrm{Nd}$ & ppm & 0.05 & ICP-MS & 23.3 & 7.55 & 5.13 & 30 & 4.42 & 51.2 \\
\hline $\mathrm{Ni}$ & ppm & 20 & ICP-MS & 70 & 60 & 50 & 40 & 50 & 20 \\
\hline $\mathrm{Pb}$ & $\mathrm{ppm}$ & 5 & ICP-MS & $<5$ & $<5$ & $<5$ & 34 & $<5$ & 63 \\
\hline $\operatorname{Pr}$ & ppm & 0.01 & ICP-MS & 7.55 & 2.01 & 1.41 & 9.48 & 1.09 & 15.9 \\
\hline $\mathrm{Rb}$ & ppm & 1 & ICP-MS & 9 & 6 & 4 & 6 & 3 & 2 \\
\hline $\mathrm{Sb}$ & ppm & 0.2 & INAA & $<0.2$ & $<0.2$ & $<0.2$ & $<0.2$ & $<0.2$ & $<0.2$ \\
\hline $\mathrm{Sb}$ & ppm & 0.2 & ICP-MS & $<0.2$ & $<0.2$ & $<0.2$ & $<0.2$ & $<0.2$ & $<0.2$ \\
\hline $\mathrm{Sb}$ & \multicolumn{3}{|c|}{ recommended } & $<0.2$ & $<0.2$ & $<0.2$ & $<0.2$ & $<0.2$ & $<0.2$ \\
\hline $\mathrm{Sc}$ & ppm & 0.1 & INAA & 9 & 7.2 & 5.5 & 9.7 & 14.8 & 16.8 \\
\hline $\mathrm{Sc}$ & ppm & 1 & FUS-ICP & 16 & 13 & 10 & 15 & 15 & 17 \\
\hline $\mathrm{Sc}$ & \multicolumn{3}{|c|}{ recommended } & 9 & 7.2 & 5.5 & 9.7 & 14.8 & 16.8 \\
\hline $\mathrm{Se}$ & ppm & 3 & INAA & $<3$ & $<3$ & $<3$ & $<3$ & $<3$ & $<3$ \\
\hline
\end{tabular}


Table 3 (Continued)

\begin{tabular}{llllllllll}
\hline Analyte & Unit & D.L. & Method & $\begin{array}{l}\text { NAu-2 } \\
\text { low S }\end{array}$ & $\begin{array}{l}\text { NAu-2 } \\
\text { mid S }\end{array}$ & $\begin{array}{l}\text { NAu-2 } \\
\text { high S }\end{array}$ & $\begin{array}{l}\text { KGa-2 } \\
\text { mid S }\end{array}$ & $\begin{array}{l}\text { NAu-2 } \\
\text { raw }\end{array}$ & $\begin{array}{l}\text { KGa-2 } \\
\text { raw }\end{array}$ \\
\hline $\mathrm{Sm}$ & ppm & 0.01 & ICP-MS & 3.38 & 1.68 & 1.14 & 5.06 & 1.09 & 7.82 \\
$\mathrm{Sn}$ & ppm & 1 & ICP-MS & 4 & 1 & 1 & 7 & $<1$ & 12 \\
$\mathrm{Sr}$ & $\mathrm{ppm}$ & 2 & FUS-ICP & 236 & 185 & 144 & 152 & 134 & 59 \\
$\mathrm{Ta}$ & $\mathrm{ppm}$ & 0.01 & ICP-MS & 4.26 & 1.55 & 1.61 & 3.19 & 0.33 & 4.43 \\
$\mathrm{~Tb}$ & $\mathrm{ppm}$ & 0.01 & ICP-MS & 0.47 & 0.28 & 0.2 & 0.63 & 0.16 & 0.82 \\
$\mathrm{Th}$ & $\mathrm{ppm}$ & 0.05 & ICP-MS & 1.55 & 0.82 & 0.53 & 9.49 & 0.34 & 16.2 \\
$\mathrm{Tl}$ & $\mathrm{ppm}$ & 0.05 & ICP-MS & $<0.05$ & $<0.05$ & $<0.05$ & $<0.05$ & $<0.05$ & $<0.05$ \\
$\mathrm{Tm}$ & $\mathrm{ppm}$ & 0.005 & ICP-MS & 0.233 & 0.133 & 0.102 & 0.251 & 0.086 & 0.288 \\
$\mathrm{U}$ & $\mathrm{ppm}$ & 0.01 & ICP-MS & 0.77 & 0.38 & 0.33 & 3.68 & 0.28 & 5.9 \\
$\mathrm{~V}$ & $\mathrm{ppm}$ & 5 & FUS-ICP & 129 & 105 & 81 & 78 & 131 & 64 \\
$\mathrm{~W}$ & $\mathrm{ppm}$ & 0.5 & ICP-MS & 545 & 360 & 209 & 360 & 2 & 9.1 \\
$\mathrm{Y}$ & $\mathrm{ppm}$ & 0.5 & ICP-MS & 15.9 & 9.4 & 7.1 & 17.6 & 4.9 & 17.3 \\
$\mathrm{Yb}$ & $\mathrm{ppm}$ & 0.01 & ICP-MS & 1.47 & 0.86 & 0.7 & 1.59 & 0.62 & 1.82 \\
$\mathrm{Zn}$ & $\mathrm{ppm}$ & 30 & ICP-MS & 90 & 70 & 60 & 50 & 130 & $<30$ \\
\hline
\end{tabular}

D.L. = detection limit

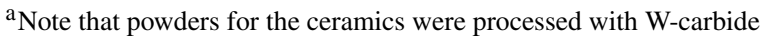

\subsection{Fusion Inductively-Coupled Plasma (FUS-ICP) and Inductively-Coupled Plasma Mass Spectrometry (ICP-MS)}

For ICP analysis, samples were prepared and analyzed at Actlabs using methods described on their web site at www.actlabs.com. Each batch contained a reagent blank, certified reference materials, and $17 \%$ replicates. Samples were mixed with a flux of lithium metaborate and lithium tetraborate and fused in an induction furnace. The melt was poured into $5 \%$ nitric acid with an internal standard and stirred until dissolved. The samples were analyzed for major oxides and selected trace elements (FUS-ICP in Tables 2 and 3) using a Thermo Jarrell-Ash ENVIRO II ICP.

For ICP-MS analysis at Actlabs, reagent blanks with and without the lithium borate flux were analyzed, as well as the method blank. Interference correction verification standards were also analyzed. Calibration was performed using USGS and CANMET certified reference materials. The sample solution was spiked with internal standards and was further diluted and introduced into a Perkin Elmer SCIEX ELAN 6000 ICP/MS using a proprietary Actlabs method.

\subsection{Microbeam Analysis of Ceramic Discs by Scanning Electron Microscopy (SEM)}

In order to determine compositional and textural homogeneity, ceramic discs were also examined using a JEOL 5800LV Scanning Electron Microscope (SEM) operating at a low vacuum of $29 \mathrm{~Pa}$, an accelerating voltage of $20 \mathrm{kV}$, and a beam current of $0.20 \mathrm{nA}$. Low vacuum was required because the ceramic rounds were placed directly in the vacuum chamber with no carbon coating or additional preparation; due to the limited availability of these calibration materials, the use of a conductive coating was avoided to preserve as much unmodified material as possible for potential future analyses with different techniques. Images were obtained using backscattered electrons (BSE) in order to highlight compositional variations associated with phases of differing average atomic weight. 


\subsection{Microbeam Analysis of Polished Thin Sections by Electron Microprobe}

Thin-sections of the ceramics were analyzed for major and some trace element components using both wavelength-dispersive spectroscopy (WDS) and energy-dispersive spectroscopy (EDS) on a JEOL 8200 Electron Probe Microanalyzer (EPMA). An accelerating potential of $15 \mathrm{keV}$ was used, with beam current of $20 \mathrm{nA}$ and spot sizes of either 1 or $10 \mu \mathrm{m}$. Standards for WDS were provided by a C.M. Taylor Company standard mount. Doubly-polished thin sections were carbon-coated to reduce charging. One to two linescans across the ceramics were performed, totaling $\sim 200$ to 350 spot analyses. The beam was positioned to avoid obvious vesicles but a point spacing of $\sim 100 \mu \mathrm{m}$ was maintained. Elements analyzed included $\mathrm{B}, \mathrm{Na}, \mathrm{Mg}, \mathrm{Al}, \mathrm{Si}, \mathrm{S}, \mathrm{Ca}$, and $\mathrm{Fe}$ in linescans with $1 \mu \mathrm{m}$ spot size for all of the ceramics. Additional linescans at $10 \mu \mathrm{m}$ spot size included Ti in the element suite; these additional linescans were performed on the KGa-2 mid S and NAu-2 low S ceramics.

\subsection{Optical Analysis}

Standard doubly-polished thin sections of the ceramics, $30 \mu \mathrm{m}$ thick, were examined with an Olympus BH-2 petrographic microscope. The sections were analyzed in both transmitted and reflected light. Point-counting (1,000 points on a $250 \mu \mathrm{m}$ grid) was used to measure the volume percentage of vesicles in each ceramic. Vesicle sizes were measured with a calibrated reticle.

\subsection{Laser-Induced Breakdown Spectroscopy (LIBS)}

LIBS data were used to assess the heterogeneity of the ceramic standards. Spectra were collected at LANL using the ChemCam flight model. Data were collected in a thermal vacuum chamber with the laser at $-10{ }^{\circ} \mathrm{C}$, producing a maximum laser energy output of $\sim 15 \mathrm{~mJ} /$ pulse. Eighteen geochemical standards plus the 10 calibration targets were analyzed at $1.6 \mathrm{~m}$ stand-off distance. The LIBS spot size $(\sim 400 \mu \mathrm{m})$ exceeded the largest grain size in the ceramics $(\sim 100 \mu \mathrm{m})$. During analysis the chamber was held at 7 Torr $\mathrm{CO}_{2}$. Data were taken at $3 \mathrm{~Hz}$, for a total of 50 shots at each of 4 analysis locations per target. Additional details on the ChemCam flight instrument and calibrations are presented in Wiens et al. (this issue). Spectra were normalized to the total emission intensity for each spectrograph and the first five spectra at each spot were discarded to discount any surface contamination.

\section{Analytical Results and Characterization of the Ceramic Targets}

\subsection{Physical and Optical Properties}

The ceramic targets based on nontronite NAu-2 are brick red with Munsell colors of 7.5YR2/4 (NAu-2 low S), 5YR2/4 (NAu-2 mid S), and 5YR1/2 (NAu-2 high S). The target based on kaolinite KGa-2 is somewhat mottled but overall very light brown in color (2.5Y4/4). Visible and near-infrared spectra of the ceramic targets are given in Wiens et al. (this issue). All of the ceramic targets are durable and retain the cylinder walls originally present in the pressed powders; they are readily cut with a diamond saw blade. As observed in prototype development, ceramics based on NAu-2 are harder than a steel probe but can be scratched with a sharp tungsten carbide probe. The ceramic based on KGa-2 is softer and can be scratched with a steel probe. 


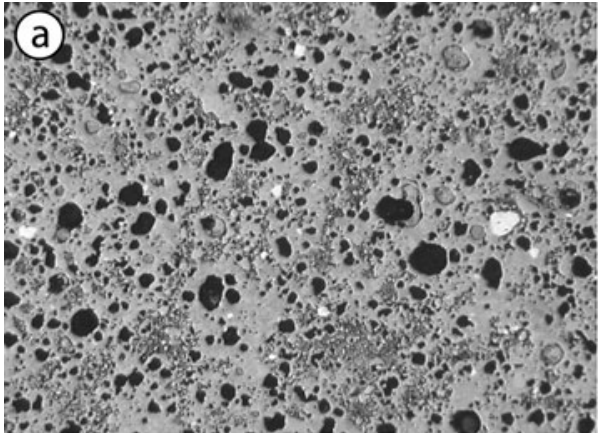

NAu-2 low $S$

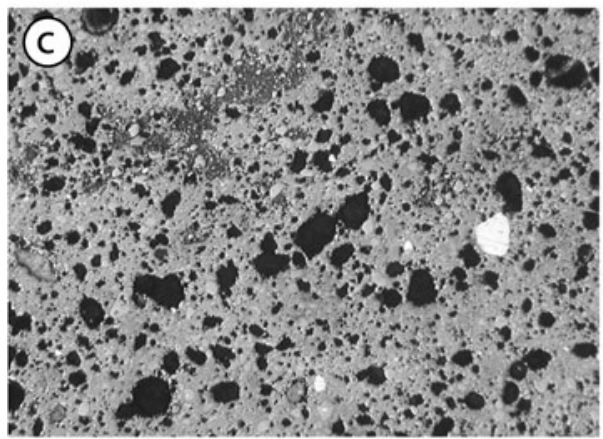

NAu-2 high $S$

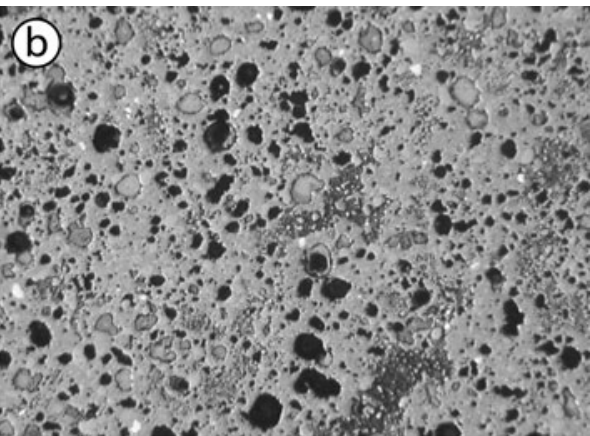

NAu-2 low S

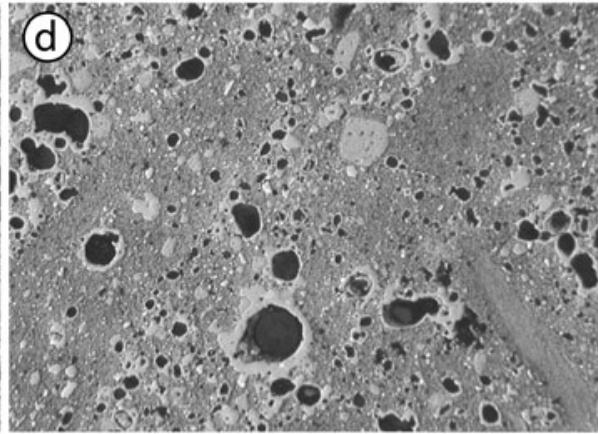

KGa-2 mid S

Fig. 4 Reflected-light photomicrographs of $30 \mu \mathrm{m}$ thick doubly-polished thin sections of ChemCam ceramic targets. Dark spots are epoxy-filled vesicles; bright grains in the NAu-2 samples are hematite

Standard doubly-polished petrographic sections of the NAu-2 ceramics are opaque in plane-polarized transmitted light. In reflected light, the polished sections of these ceramics are vesicular with selvages of vitrification surrounding most vesicles (Fig. 4). Vesicle linings are not coated by any vapor-phase crystals but do entrain small grains of a few $\mu \mathrm{m}$. In the ceramics based on NAu-2, vesicle abundance ranges from $\sim 20 \%$ in the ceramic of lowest sulfur content to $\sim 30 \%$ for the highest sulfur content. In the KGa-2 mid-S ceramic, vesicle abundance is $\sim 20 \%$. Vesicle sizes are generally $<100 \mu \mathrm{m}$, although a few of the vesicles in the KGa-2 mid-S ceramic range up to 200-300 $\mu \mathrm{m}$. In both the NAu-2 and KGa- 2 ceramics, fine grain size $(<30 \mu \mathrm{m})$ is observed in zones surrounding vesicles; grains of $\sim 30 \mu \mathrm{m}$ are typical elsewhere but coarser grains (up to $100 \mu \mathrm{m}$ ) occur in areas not adjacent to vesicles. Commonly the coarsest grains in the NAu-2 ceramics are of anhedral hematite that may be up to $100 \mu \mathrm{m}$ in diameter.

The petrographic section of the KGa-2 ceramic has a more complex fabric than the NAu2 ceramics. Subangular bodies of very fine-grained matrix up to $2 \mathrm{~mm}$ in size are distributed in a coarser matrix (Fig. 4d). Because all of the pressed powders were sintered while freestanding and all maintained cylindrical form without distortion or flowing, these bodies are unlikely to be chilled rim portions that migrated into the body of the ceramic. Rather, the bodies of finer grain size are believed to represent heterogeneity in heating and cooling within the KGa-2 pressed powder cylinders. 


\subsection{Bulk Chemical Composition}

Compiled major- and minor-element chemical analyses of materials used to produce the ceramics are listed in Table 1; analyses of the finished ceramics are listed in Tables 2 and 3. The bulk chemical compositions of the four ceramics match the predicted compositions within $5 \%$ relative for all oxides present at $>1 \%$. The conservation of weight on firing and retention of $\mathrm{S}$ abundance within $1 \%$ of the pre-firing abundances within the mixed powder (except in the NAu-1 low S ceramic, which is within $\sim 10 \%$ ) indicate that volatile element loss on firing was minimal. Each ceramic target has an average composition listed in bold text in Table 2, based on the average of XRF and FUS-ICP analyses, that is close to the planned, predicted value. Boron analyses however are problematic. The Actlabs PGNAA $\mathrm{B}_{2} \mathrm{O}_{3}$ measurements range from 8.34 to $8.95 \mathrm{wt} \%$, whereas expected $\mathrm{B}_{2} \mathrm{O}_{3}$ content of the ceramics is $7.44 \mathrm{wt} . \%$. This discrepancy may arise because the boron content in the ceramics is about twice the recommended upper limit of the PGNAA method (see Sect. 2.4). For comparison, the multi-point microprobe averages for $\mathrm{B}_{2} \mathrm{O}_{3}$ vary from 5.8 to $7.4 \mathrm{wt} . \%$, but for reasons discussed in Sect. 3.4 we find that low microprobe totals are common and the measured averages are generally lower than actual bulk concentration. The only usable direct measurement of B is that of the PGNAA, so that is reported in Table 2, although we do not use the PGNAA boron data in presenting the preferred value for the ceramics because of the method limitations. For the purposes of Table 2 we recognize the limitations on analysis for both $\mathrm{Li}$ and $\mathrm{B}$ and use the as-weighed lithium tetraborate powder abundance, used in preparing the ceramics, for the preferred composition.

\subsection{X-Ray Diffraction}

Powder X-ray diffraction patterns of the four ceramics are compared in Fig. 5 and estimates of weight abundance based on full-pattern fitting are tabulated in Table 4. All of the ceramics developed a significant amount of X-ray amorphous "glassy" binding material that is manifested as a broad, asymmetric rise in the diffraction background that peaks at $\sim 24^{\circ}$ 2-theta $(\mathrm{Cu} \mathrm{K} \alpha)$. This X-ray amorphous component includes borosilicate(s) and its abundance cannot be estimated by full-pattern fitting. However, the conservation of sulfur on firing (see discussion of chemical analyses), microprobe data indicating that $\mathrm{S}$ is correlated with $\mathrm{Ca}$ (i.e., present as crystalline $\mathrm{CaSO}_{4}$ ), and the relative constancy of weight before and after firing allow the abundance of anhydrite to be used to adjust the relative proportions of crystalline and X-ray amorphous material accordingly. The results as presented in Table 4 are semi-quantitative.

All of the ceramics based on nontronite NAu- 2 contain anhydrite, hematite, cristobalite, and remnant grains of plagioclase and augite from the powdered basalt. In the NAu- 2 ceramic with the lowest sulfate content, remnant grains of plagioclase and augite are most abundant. Complex phases including silicates that incorporate $\mathrm{Li}$ and/or $\mathrm{B}$ from the flux are likely present as well; of these, virgilite (a lithium-aluminum silicate, $\mathrm{LiAl}_{2} \mathrm{Si}_{2} \mathrm{O}_{6}$ ) occurs in all of the nontronite-based NAu ceramics. There is a bit of serendipity in the formation of virgilite within these ceramics, for the virgilite type locality is Macusani, Peru (French et al. 1978), where it was discovered within Macusani volcanic glass that happens to be used as the sole natural volcanic glass calibration target on ChemCam (Fabre et al. 2011). Virgilite also occurs synthetically in other lithium aluminum silicate glass-ceramics that are sintered at low temperature (e.g., Serbena et al. 2011).

The ceramic based on kaolinite KGa-2 contains anhydrite with remnant grains of plagioclase and augite from the powdered basalt. Virgilite may be present, but in trace amounts 

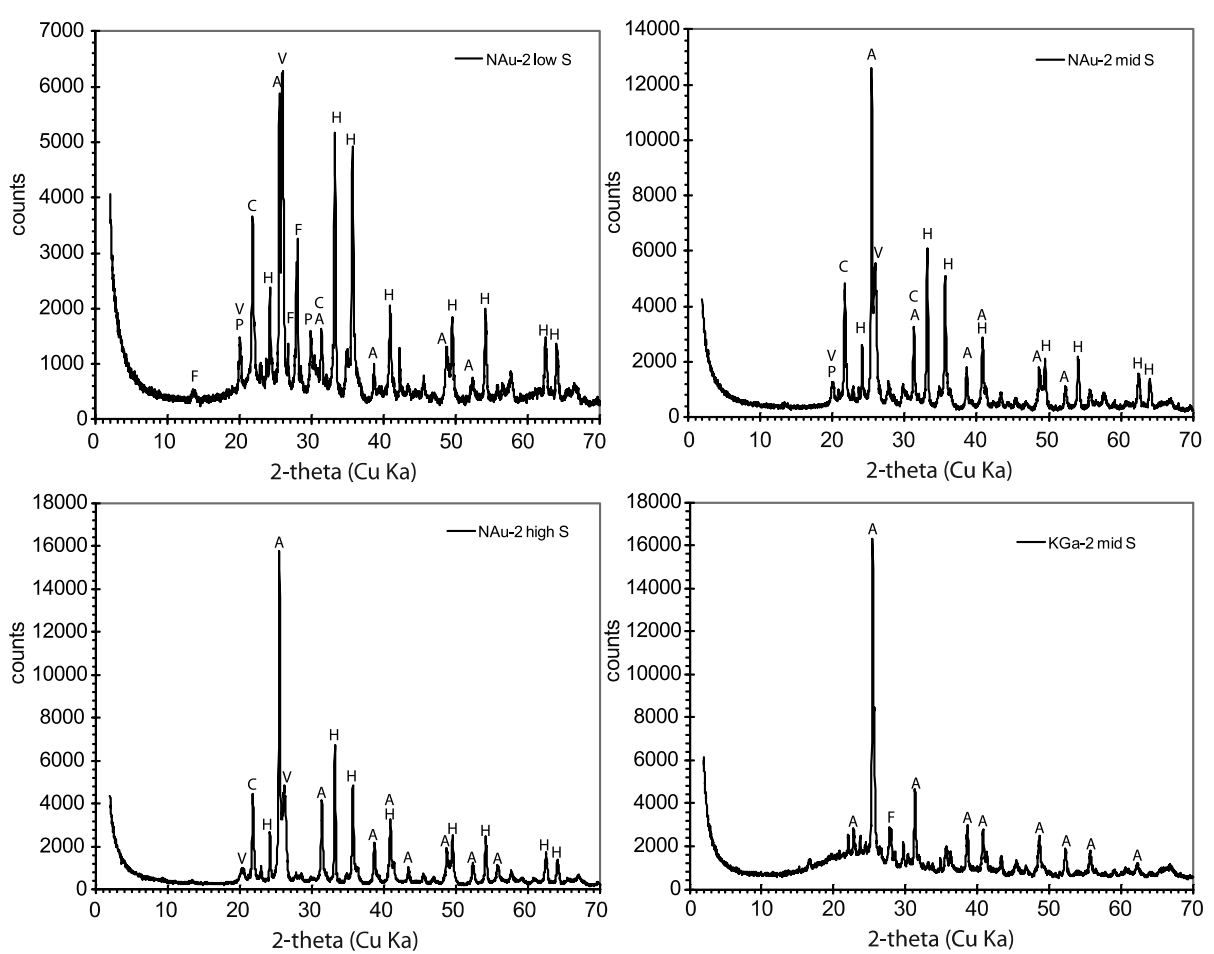

Fig. 5 Powder X-ray diffraction patterns of the four ChemCam ceramics. Mineral symbols are A = anhydrite, $\mathrm{C}=$ cristobalite, $\mathrm{F}=$ feldspar, $\mathrm{H}=$ hematite, $\mathrm{P}=$ pyroxene (augite), $\mathrm{V}=$ virgilite. All data were collected at the same conditions and variation in the scale of the vertical axis is sample-dependent

difficult to confirm by XRD. The amorphous diffraction background is higher in the KGa2 mid S ceramic than in any of the nontronite-based NAu-2 ceramics and glass linings of vesicles are more prominent in the KGa-2 ceramic than in the NAu-2 ceramics. The glassy component of the KGa-2 ceramic may contain most of the Li (and likely B) contributed from flux, accounting for the apparent absence of virgilite.

As noted in Sect. 1.2, the discs were synthesized with anhydrite but preliminary XRD analyses of "sawdust" collected during cutting of discs from the ceramic cylinders identified gypsum as well as anhydrite. However, as data accumulated from LIBS analysis of the ceramics it was noted that hydrogen detections were absent or very low and not in line with the occurrence of gypsum in any significant abundance. Because of this discrepancy, representative discs from each of the ceramics were sacrificed to be crushed for XRD analysis; none of these samples contained gypsum. It is apparent that even though the cylinders were cut with ethanol some hydration of anhydrite did occur, likely caused by hydration of the ethanol, to form gypsum in the fines collected from the saw. The XRD data summarized in Table 4 report the more accurate analyses obtained from crushed discs.

\subsection{Electron Microbeam Results}

Table 5 shows the average, standard deviation, minimum, and maximum values for $\mathrm{Si}, \mathrm{Al}$, $\mathrm{Ca}, \mathrm{Fe}, \mathrm{Mg}, \mathrm{Na}, \mathrm{S}$, and $\mathrm{B}$, recalculated as oxide weight percent, as analyzed by electron 
Table 4 Phase detection and abundances (wt.\%) determined by XRD in the ChemCam ceramic targets

$\mathrm{a}_{\operatorname{tr}}=\operatorname{trace}(<1 \%)$

\begin{tabular}{lllll}
\hline & $\begin{array}{l}\text { NAu-2 } \\
\text { low S }\end{array}$ & $\begin{array}{l}\text { NAu-2 } \\
\text { mid S }\end{array}$ & $\begin{array}{l}\text { NAu-2 } \\
\text { high S }\end{array}$ & $\begin{array}{l}\text { KGa-2 } \\
\text { mid S }\end{array}$ \\
\hline Plagioclase & 7 & 2 & $\operatorname{tr}^{\mathrm{a}}$ & 4 \\
Augite & 6 & 3 & $\operatorname{tr}$ & 2 \\
Cristobalite & 4 & 5 & 5 & - \\
Hematite & 10 & 9 & 9 & - \\
Virgilite & 16 & 16 & 16 & - \\
Anhydrite & 10 & 23 & 36 & 23 \\
Amorphous & 47 & 42 & 33 & 71 \\
\hline
\end{tabular}

Table 5 Summary statistics for electron microprobe data

\begin{tabular}{lrrrrrrrr}
\hline & $\mathrm{SiO}_{2}$ & $\mathrm{Al}_{2} \mathrm{O}_{3}$ & $\mathrm{CaO}$ & $\mathrm{FeO}$ & $\mathrm{MgO}$ & $\mathrm{Na}_{2} \mathrm{O}$ & $\mathrm{SO}_{3}$ & $\mathrm{~B}_{2} \mathrm{O}_{3}$ \\
\hline NAu-2 low S & & & & & & & & \\
average & 42.7 & 7.8 & 7.5 & 17.1 & 3.8 & 1.7 & 4.5 & 7.4 \\
st. dev. & 6.5 & 4.6 & 3.1 & 6.8 & 5.5 & 0.9 & 2.3 & 4.8 \\
max & 55.7 & 24.2 & 18.9 & 38.0 & 31.0 & 4.9 & 11.6 & 23.0 \\
min & 12.1 & 0.0 & 0.2 & 2.1 & 0.2 & 0.0 & 0.0 & 0.0 \\
& & & & & & & & \\
NAu-2 mid S & & & & & & & & \\
average & 40.7 & 6.1 & 10.5 & 16.5 & 1.8 & 1.2 & 11.1 & 5.9 \\
st. dev. & 8.1 & 4.4 & 4.3 & 6.5 & 2.9 & 0.8 & 6.1 & 3.4 \\
max & 67.5 & 28.0 & 26.1 & 32.4 & 34.4 & 5.3 & 36.5 & 16.6 \\
min & 20.8 & 0.7 & 1.5 & 0.4 & 0.0 & 0.1 & 0.0 & 0.0 \\
NAu-2 high S & & & & & & & & \\
average & 34.9 & 4.1 & 14.2 & 15.5 & 1.1 & 0.8 & 18.0 & 5.8 \\
st. dev. & 10.9 & 4.2 & 6.4 & 6.5 & 2.1 & 0.8 & 9.3 & 3.2 \\
max & 84.2 & 32.1 & 31.2 & 32.5 & 27.5 & 6.7 & 43.8 & 19.5 \\
min & 8.2 & 0.2 & 0.7 & 0.4 & 0.0 & 0.1 & 0.0 & 0.0 \\
KGa-2 mid S & & & & & & & & \\
average & 32.4 & 21.8 & 9.1 & 2.1 & 1.5 & 0.8 & 10.4 & 6.0 \\
st. dev. & 7.4 & 5.9 & 3.5 & 3.5 & 4.6 & 0.6 & 5.0 & 7.4 \\
max & 67.7 & 37.7 & 20.2 & 29.0 & 42.3 & 3.9 & 20.9 & 29.8 \\
min & 19.3 & 0.0 & 0.1 & 0.5 & 0.0 & 0.0 & 0.0 & 0.0 \\
\hline
\end{tabular}

Only analysis points with totals of 90-100\% are tabulated. This includes 194 analyses for NAu-2 low S, 183 for NAu-2 mid S, 191 for NAu-2 High S, and 215 for KGa-2 mid S

microprobe (Ti data are not tabulated as they were only obtained from a subset of the analytical points). Approximately 200 analysis points are represented for each of the ceramics and only points with totals between $90-100 \%$ are tabulated. The causes of low analytical totals are discussed in more detail below.

Most of the points analyzed by electron microprobe contained both $\mathrm{Si}$ and $\mathrm{S}$ or $\mathrm{Si}$ and $\mathrm{B}$, which do not occur together in any crystalline phase identified by XRD in the ceramics. This indicates that most analysis spots were mixtures of several minerals or glass within the 
diameter of the microprobe beam (either 1 or $10 \mu \mathrm{m}$ ). Nevertheless, several of the points analyzed at these spot sizes were of individual grains of plagioclase, augite, olivine, and (rarely) ilmenite that represent nonmelted minerals of the Totavi basalt. These individual crystalline relics from the basalt, coarse enough to contain most of the $1-10 \mu \mathrm{m}$ microprobe beam, comprise $<2 \%$ of the points analyzed. Individual grains of hematite in the NAu2 ceramics, produced from orthorhombic $\mathrm{Fe}_{2} \mathrm{O}_{3}$ (Fig. 2) on firing of the ceramics, were avoided.

Statistical analysis of the microprobe data shows little correlation between any of the elements except $\mathrm{Ca}$ and $\mathrm{S}$, as expected for samples containing anhydrite. The $\mathrm{Ca}-\mathrm{S}$ correlation is strongest in the high-S NAu- 2 ceramic $\left(R^{2}=0.97\right)$, less in the mid-S NAu- 2 ceramic $\left(R^{2}=0.92\right)$, and very poor in the low-S ceramic $\left(R^{2}=0.28\right)$. Poor correlation in the low $\mathrm{S}$ composition is attributable to the relative increase in volumetric proportion of Ca-bearing augite and plagioclase from the Totavi basalt. In the KGa-2 mid-S ceramic, the $\mathrm{Ca}-\mathrm{S}$ correlation is also modest $\left(R^{2}=0.73\right)$ and poorer than the correlation between $\mathrm{Mg}$ and $\mathrm{Fe}$ $\left(R^{2}=0.87\right)$. The association of $\mathrm{Fe}$ with $\mathrm{Mg}$ in the $\mathrm{KGa}-2$ ceramic arises because $\mathrm{Fe}$ is not segregated from $\mathrm{Mg}$ to form hematite as in the NAu-2 ceramics; in the KGa-2 ceramic these two elements are associated in remnant augite and (to lesser extent) olivine of the Totavi basalt powder. It is notable that the highest $\mathrm{SO}_{3}$ content observed in any of the microprobe analytical points in all of the ceramics was $44 \mathrm{wt} . \%$, far less than the $58.8 \mathrm{wt} \% \mathrm{SO}_{3}$ of stoichiometric anhydrite. This indicates that none of the anhydrite in any of the ceramics was coarse enough to contain the electron microprobe beam.

Despite caution taken to avoid visible vesicles, many of the microprobe analysis points have low totals ( $<90 \mathrm{wt} . \%$ and as low as $70 \mathrm{wt} . \%)$. In part this is because of the presence of unanalyzed lithium at an abundance of $1.6 \mathrm{wt} . \% \mathrm{Li}_{2} \mathrm{O}$ in the bulk composition of all of the ceramics and possibly concentrated locally in either a glass phase or, in the NAu- 2 ceramics, in the mineral virgilite $\left(\sim 4 \mathrm{wt} . \% \mathrm{Li}_{2} \mathrm{O}\right)$. In addition, $\mathrm{Fe}$ is reported as $\mathrm{FeO}$ but includes some fraction of ferric iron. Titanium was also not a part of the analysis suite in all microprobe analyses but where analyzed the abundance is low (KGa-2 mid S averages 1.4 wt. $\% \mathrm{TiO}_{2}$ and NAu-2 low S averages $0.4 \mathrm{wt} . \%$ ). The lowest totals are in large part a result of microporosity. Totals below $90 \mathrm{wt} \%$ are particularly common in the KGa-2 ceramic (55\% of all analysis spots) and the NAu-2 low S ceramic (43\%), but rare in the NAu-2 mid S ceramic ( $7 \%$ ) and the NAu-2 high S ceramic (5\%). The greater success of microprobe analysis of the higher-sulfur nontronite-based ceramics may have several causes but is believed to be principally associated with better matrix fusion (less microvesicularity) and with integration of anhydrite, virgilite, and a glass phase into a fine-grained and relative homogeneous glass ceramic. Unfortunately, the great variability in microprobe analytical totals limits the use of microprobe data in evaluating homogeneity of the ceramics.

Figure 6 compares ceramic target backscattered electron (BSE) surface textures of representative discs of the four ceramics. The brightest grains in BSE images of the NAu-2 samples are mostly hematite. All samples have vesicles $\sim 10-100 \mu \mathrm{m}$ in diameter, but a few larger vesicles (to $300 \mu \mathrm{m}$ ) occur in the KGa-2 mid S ceramic. All three NAu-2 samples have a consistent surface texture at the $50 \mu \mathrm{m}$ scale, while the KGa-2 surface texture is more varied. By visual inspection prior to SEM analysis, the NAu-2 low S ceramic showed some evidence for smoother and rougher surfaces throughout the disc. However, at $100 \times$ magnification there is no evidence for textural differences within the disc. Similarly, although in visual inspection the three NAu-2 ceramics appear to have increasing amounts of very faint 'mottling' in color from low S (not mottled) to high S (more mottled; Fig. 1b), these differences were not observed in BSE and do not appear to correlate with any compositional heterogeneity across the discs. 


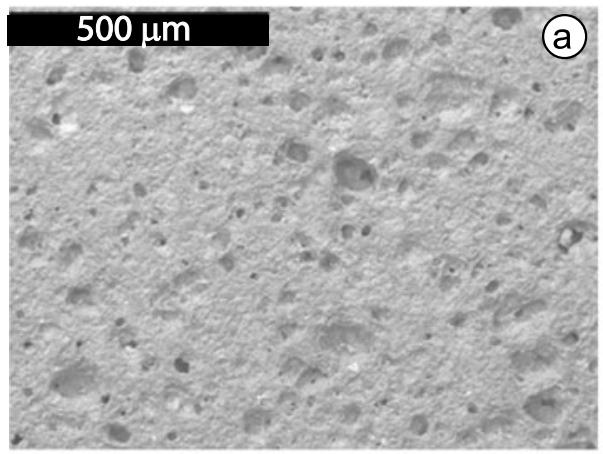

NAu-2 low $S$

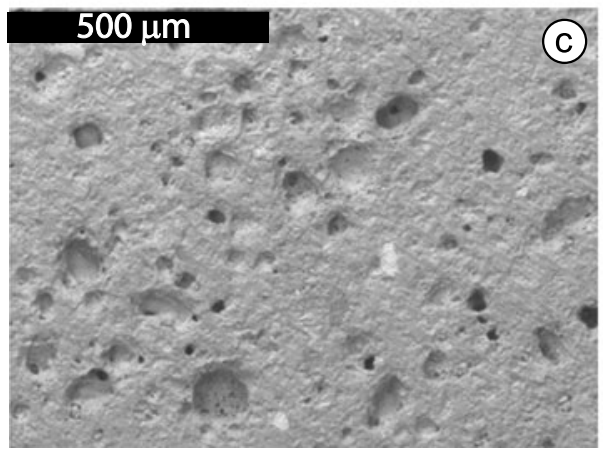

NAu-2 high S

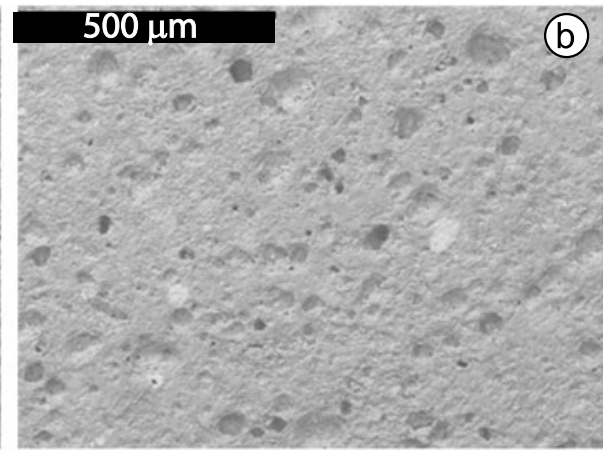

NAu-2 mid S

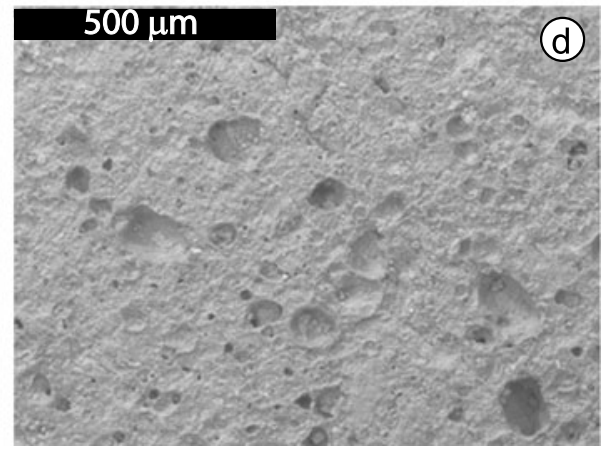

KGa-2 mid S

Fig. 6 Scanning Electron Microscopy (SEM) backscattered electron (BSE) images of ceramic calibration target surfaces at $100 \times$ magnification. Scale bars in each image (black lines) are $500 \mu \mathrm{m}$. There are numerous rounded, shallow vesicles in all samples. Bright grains of $\sim 30 \mu \mathrm{m}$ can be seen in all samples, in particular the NAu-2 suite, where most of these grains are hematite

\subsection{Laser-Induced Breakdown Spectroscopy (LIBS) Assessment of Composition and Heterogeneity}

Examples of LIBS spectra for each ceramic are shown in Fig. 7. The ceramic targets were assessed for heterogeneity in several ways. These included visual inspection of the spectra and examination of line intensity variations between four different spots within each ceramic. Specific line intensity variations between the ceramic compositions were compared to other samples of reference composition. The other samples include a picrite glass that is one of the ChemCam glass calibration standards (Fabre et al. 2011) on Curiosity, a sample of the sulfate mineral melanterite (MHC2319), and several geostandards with accepted, recommended compositions (andesite AGV-2, andesite JA-2, basalt BIR-1, stream sediment STSD-1, and shale SGR-1). Statistical analysis included evaluation of variance in peak intensities between the four analyzed spots within each sample.

Visual inspection of all 200 spectra for each ceramic (50 spectra for each of four spots) was conducted. This inspection revealed no obvious differences in the form of missing or new major peaks. Second, for each sample the intensity at every wavelength channel was examined to determine if it was within the $99 \%$ confidence level based on the standard deviation of the average intensity for the four analysis spots. Two spots were found to be significantly different: a spot in NAu-2 high $\mathrm{S}$ that is relatively low in $\mathrm{Li}$ and $\mathrm{Ca}$ and high in 
Fig. 7 Example LIBS spectra of each ceramic; NAu-2 high $\mathrm{S}$ (green), NAu-2 mid S (black), $\mathrm{NAu}-2$ low $\mathrm{S}$ (red), and $\mathrm{KGa}-2$ mid $\mathrm{S}$ (blue). Plots are divided into three spectral ranges: 240-340 nm (top), 380-470 nm (middle), and 490-860 nm (bottom). Each spectrum is the average of 180 single shot spectra across 4 analysis locations; spectra have been normalized to the total emission, multiplied by 1000 and then offset by 5 units for clarity

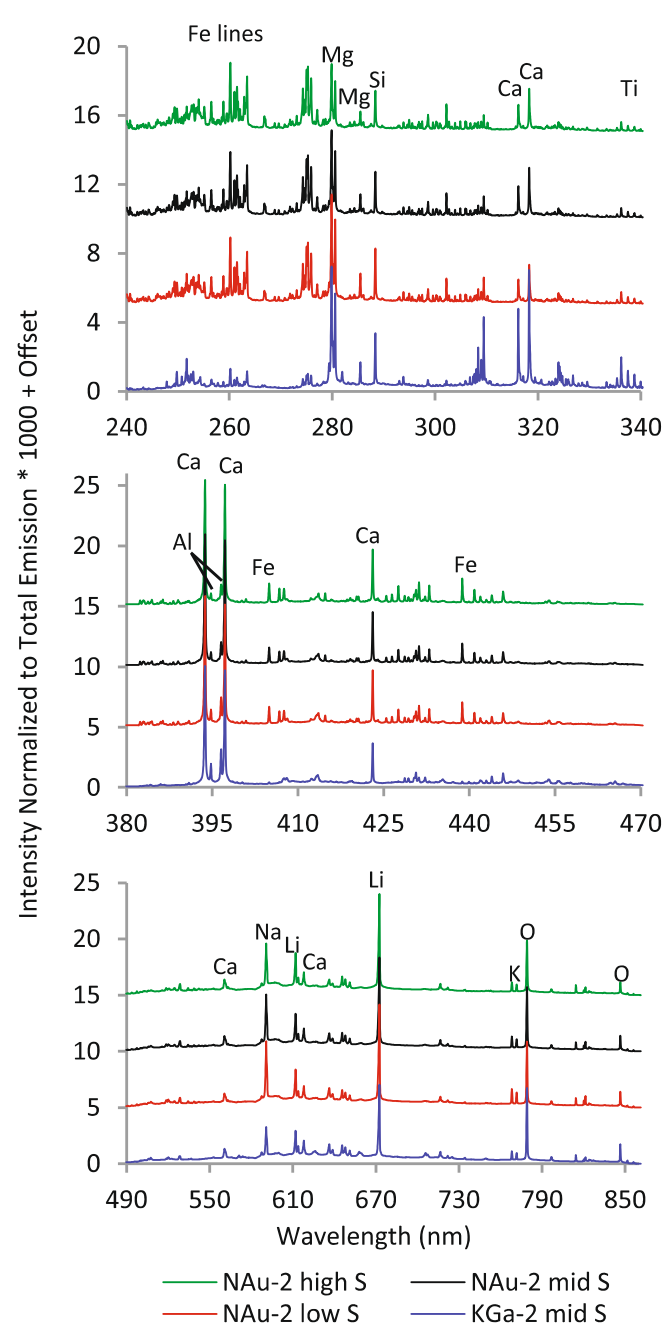

$\mathrm{Ti}$ and $\mathrm{Ba}$, and a spot in NAu-2 mid $\mathrm{S}$ that is relatively low in $\mathrm{Li}, \mathrm{Ca}, \mathrm{Fe}, \mathrm{Na}$ and $\mathrm{O}$. Figure 8 shows bivariate plots of $\mathrm{Na}$ vs. $\mathrm{Mg}$ and $\mathrm{Li}$ vs. $\mathrm{Ca}$ for all four analyses in each sample, with standard analytical errors. The plot of $\mathrm{Na}$ vs. $\mathrm{Mg}$ is typical of most bivariate plots in that the range of LIBS peak intensity variation in all four ceramics is comparable to the range for most other samples, including the geostandard powders. However, the plot of Li vs. Ca shows distinct outliers of lower intensity in both elements for NAu-2 mid S and NAu-2 high $\mathrm{S}$, as well as a broad range of variation in the $\mathrm{KGa}-2$ mid $\mathrm{S}$ ceramic. Outliers such as these have been observed in some powdered geostandards as well. Because the outlier in NAu-2 mid $\mathrm{S}$ is marked by decrease in peak intensity of most major elements in the ceramic, the cause of variation appears to be a drop in total LIBS intensity for all elements at that spot rather than compositional variation within the ceramic.

Notably absent in the statistical analysis of LIBS results for the four ceramics is a significant role for any of the sulfur emission lines, despite the great range of sulfur composition. This is discussed further below. 

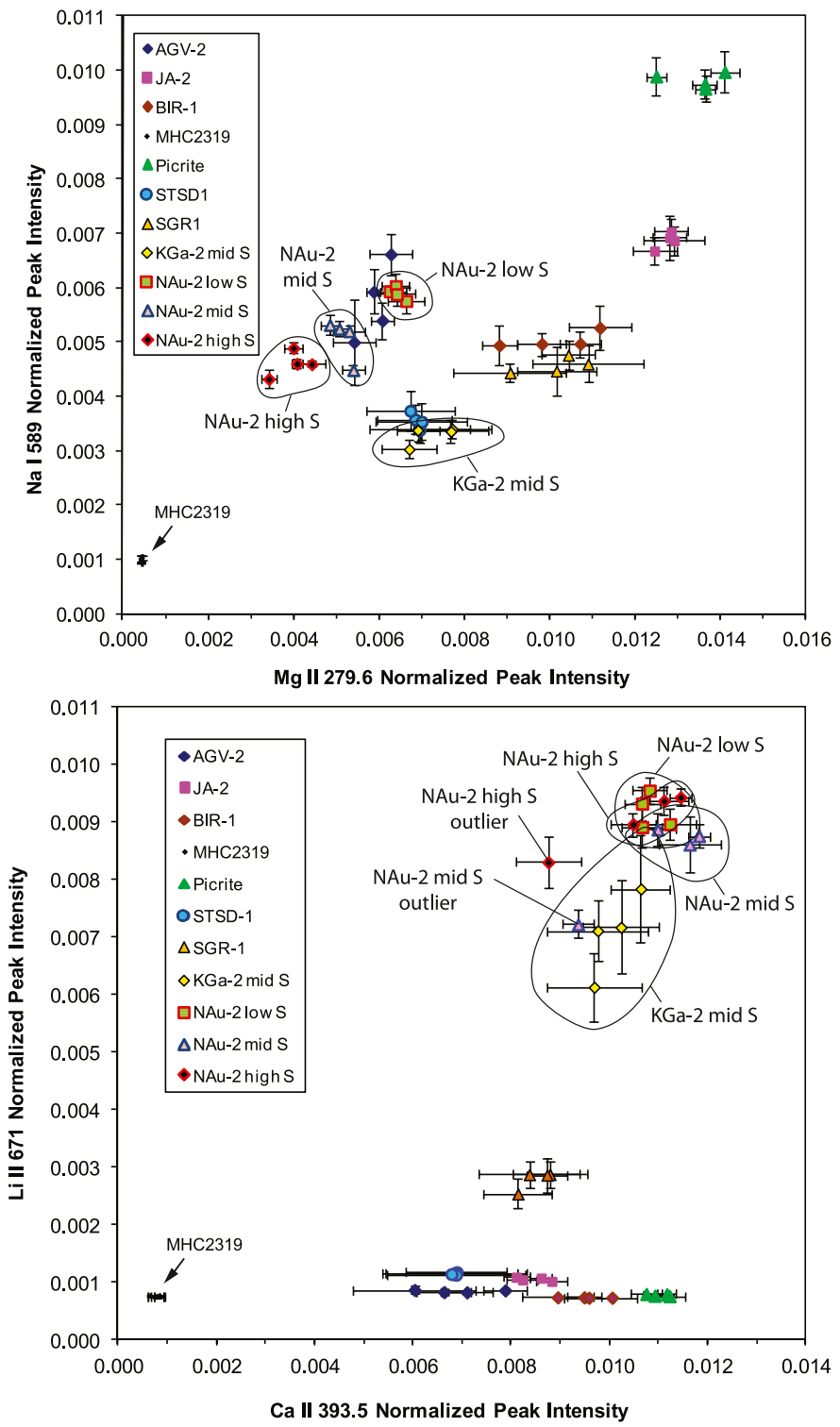

Fig. 8 Bivariate plots of LIBS emission line intensities for lines at $589 \mathrm{~nm}$ (neutral Na) vs. $279.6 \mathrm{~nm}$ (singly-ionized Mg) (upper plot) and $671 \mathrm{~nm}$ (singly-ionized Li) vs. $393.5 \mathrm{~nm}$ (singly-ionized Ca) (lower plot), with analytical error bars representing standard deviation of 45 LIBS shots within each spot (50 shots, with the first 5 discarded to account for any surface effects). For all samples, four different spots were analyzed. Fields for the four ceramics are shown, including error bars, except for two outliers (NAu-2 mid S and NAu-2 high S) in the $671 \mathrm{~nm}$ vs. $393.5 \mathrm{~nm}$ plot where emission line intensities for both $\mathrm{Li}$ and $\mathrm{Ca}$ lines are diminished. The samples shown for comparison include the ChemCam standard picrite glass (Fabre et al. 2011), an Fe-sulfate mineral (melanterite MHC2319), several powdered geostandards (andesite AGV-2, andesite JA-2, basalt BIR-1), a quartz-feldspar-amphibole-chlorite-mica stream sediment (STSD-1), and Green River shale (SGR-1) 


\section{Application of S-Bearing Granular Ceramics as ChemCam Calibration Targets on Mars}

Granular ceramic targets are secondary to homogeneous glasses for chemical calibration of LIBS on Mars. Ceramics do however fill a unique role in calibration, particularly in representing a fine-grained mineral and glass mixture (Table 4), in their component of claymineral chemistry, and in their range of sulfur content present as sulfate. The chemical data compiled in Tables 2 and 3 provide an accurate summary of the bulk compositions of the ceramics. For comparative purposes, the chemical analyses of the shergottite glass obtained for this study are in excellent agreement with those from Fabre et al. (2011), indicating that analyses in Tables 2 and 3 of this paper can be compared along with the glass target compositions from that study.

Compared to the homogeneous glass calibration targets, ceramic targets are more heterogeneous on a fine scale, with vitrified, granular, and vesicular features ranging in size up to $\sim 100 \mu \mathrm{m}$. The target based on kaolinite, $\mathrm{KGa}-2 \mathrm{mid} \mathrm{S}$, is more texturally heterogeneous, with glass-lined vesicles up to $300 \mu \mathrm{m}$ and fine-grained enclaves up to $\sim 2 \mathrm{~mm}$. However, LIBS analyses of the ceramics (Fig. 8) suggest that compared to the KGa-2 ceramic there is either (1) more compositional variation, or (2) spot variation in total LIBS emission, in the mid-S and high-S ceramics based on nontronite (NAu-2).

Analysis of the LIBS spectra for the ceramics shows that, as reported by Salle et al. (2004) and Dyar et al. (2011), direct detection of sulfur is difficult in LIBS analyses in a martian environment. The latter paper points out that transition probabilities for even the strong S lines are significantly smaller (at least an order of magnitude) than those for other "major" elements, so that $\mathrm{S}$ lines may be difficult to detect by routine methods, even in high$\mathrm{S}$ samples. Although the NAu-2 high S composition contains $25 \% \mathrm{SO}_{3}(10 \% \mathrm{~S})$ by weight, the $\mathrm{S}$ emission lines in LIBS at 545.5 and $564.7 \mathrm{~nm}$ are not well-resolved due to interference from the much stronger Fe emission in these compositions (this is not an issue in the KGa-2 mid S ceramic). Dudragne et al. (1998) suggest that the presence of sulfur induces chemical matrix effects in the remainder of the spectrum, potentially allowing a partial least squares (PLS) algorithm to determine the presence of $S$ even in the absence of its emission lines. Dyar et al. (2011) did not obtain good results in S analysis using the entire LIBS spectrum, but showed that isolating specific subsets of the LIBS wavelength ranges near the $S$ emission line locations allowed determination of non-zero correlation coefficients for PLS; this strategy was particularly successful for sulfate minerals. Quantification of sulfur using ChemCam data will be addressed in a forthcoming calibration paper because it presents challenges to routine PLS analyses and requires special procedures to get optimal results. These will be needed to mitigate effects from the Fe interference in ChemCam operations at Gale Crater, where sulfate phases are important components of sedimentary deposits that may also contain significant amounts of Fe-rich nontronite and basaltic detritus. However, comparative analytical results using APXS and potentially also CheMin and SAM at Gale Crater will refine the analytical methods for all elements. In addition, 'round-robin' blind samples and shared standards will be analyzed using flight-equivalent equipment for ChemCam, APXS, CheMin, and SAM; this should ensure proper characterization of samples at the Gale Crater site.

It is evident from the properties of the ceramics that heterogeneity of chemical composition is greater in the ceramic targets than in the homogeneous glasses (Fabre et al. 2011) that are carried in the ChemCam standard holder on Curiosity. However, the ceramics fill a unique role by adding potential calibration for S-bearing compositions. Many of the sediment and soil samples that will be encountered by Curiosity may contain the three major 
geochemical components present in the ceramic targets: basaltic detritus, phyllosilicates (albeit in altered phase form within the ceramics), and sulfate. The ChemCam ceramics provide realistic targets for evaluating LIBS analysis of fine-grained S-rich samples on Mars.

Acknowledgements This work was supported by NASA grants NNG06GH35G and NNX09AL21G and by LANL internal funding. We are grateful to staff members at Actlabs in Ancaster, Ontario for their excellent analytical work on these challenging samples. Support by M. Spilde in electron microbeam analysis is greatly appreciated. Comments from two anonymous reviewers helped to improve the manuscript and are gratefully acknowledged.

Open Access This article is distributed under the terms of the Creative Commons Attribution License which permits any use, distribution, and reproduction in any medium, provided the original author(s) and the source are credited.

\section{References}

D.L. Bish, J.W. Carey, D.T. Vaniman, S.J. Chipera, Stability of hydrous minerals on the martian surface. Icarus 164, 96-103 (2003)

S.J. Chipera, D.L. Bish, Baseline studies of the Clay Minerals Society source clays: Powder X-ray diffraction analyses. Clays Clay Miner. 49, 398-409 (2001)

A.N. Christensen, M. Olesen, Y. Cerenius, T.R. Jensen, Formation and transformation of five different phases in the $\mathrm{CaSO}_{4}-\mathrm{H}_{2} \mathrm{O}$ system: Crystal structure of the subhydrate $\beta-\mathrm{CaSO}_{4} \cdot 0.5 \mathrm{H}_{2} \mathrm{O}$ and soluble anhydrite $\mathrm{CaSO}_{4}$. Chem. Mater. 20, 2124-2132 (2008)

B.C. Clark, R.V. Morris, S.M. McLennan et al., Chemistry and mineralogy of outcrops at Meridiani Planum. Earth Planet. Sci. Lett. 240, 73-94 (2005)

L. Dudragne, P. Adam, J. Amouroux, Time-resolved laser-induced breakdown spectroscopy: Application for qualitative and quantitative detection of fluorine, chlorine, sulfur, and carbon in air. Appl. Spectrosc. 52, 1321-1327 (1998)

M.D. Dyar, J.M. Tucker, S. Humphries, S.M. Clegg, R.C. Wiens, M.D. Lane, Strategies for Mars remote Laser-Induced Breakdown Spectroscopy analysis of sulfur in geological samples. Spectrochim. Acta B (2011). doi:10.1016/j.sab.2010.11.016

C. Fabre, S. Maurice, A. Cousin, R.C. Wiens, O. Forni, V. Sautter, D. Guillaume, Onboard calibration igneous targets for the MSL/ChemCam LIBS instrument. Spectrochim. Acta B (2011). doi:10.1016/j.sab. 2011.03.012

B.M. French, P.A. Jezek, D. Appleman, Virgilite: A new lithium aluminum silicate mineral from the Macusani glass, Peru. Am. Mineral. 63, 461-465 (1978)

J. Grotzinger, Beyond water on Mars. Nat. Geosci. 2, 231-233 (2009)

J.P. Grotzinger, J.F. Bell III, K. Herkenhoff et al., Sedimentary textures formed by aqueous processes, Erebus crater, Meridiani Planum. Mar. Geol. 34, 1085-1088 (2006)

J.L. Keeling, M.D. Raven, W.P. Gates, Geology and characterization of two hydrothermal nontronites from weathered metamorphic rocks at the Uley graphite mine, South Australia. Clays Clay Miner. 48, 537548 (2000)

P.L. King, S.M. McLennan, Sulfur on Mars. Elements 6, 107-112 (2010)

S. Maurice et al., The ChemCam Instruments on the Mars Science Laboratory (MSL) rover: Science objectives and Mast Unit. Space Sci. Rev. (this issue)

S.M. McLennan, J.P. Grotzinger, The sedimentary rock cycle of Mars, in The Martian Surface: Composition, Mineralogy, and Physical Properties, ed. by J.F. Bell III (Cambridge Univ. Press, Cambridge, 2009), pp. 541-577

S.M. McLennan, J.F. Bell III, W.M. Calvin, Provenance and diagenesis of the evaporite-bearing Burns formation, Meridiani Planum, Mars. Earth Planet. Sci. Lett. 240, 95-121 (2005)

R.E. Milliken, D.L. Bish, Sources and sinks of clay minerals on Mars. Philos. Mag. 90, 2293-2308 (2010)

R.E. Milliken, J.P. Grotzinger, B.J. Thomson, Paleoclimate of Mars as captured by the stratigraphic record in Gale Crater. Geophys. Res. Lett. 37 (2010). doi:10.1029/2009GL041870

K. Norrish, J.T. Hutton, An accurate X-ray spectrographic method for the analysis of a wide range of geological samples. Geochim. Cosmochim. Acta 33(4), 431-453 (1969). doi:10.1016/0016-7037(69)90126-4

J.M. Rhodes, Geochemical stratigraphy of lava flows sampled by the Hawaii Scientific Drilling Project. J. Geophys. Res. Solid Earth 101(B5), 11729-11746 (1996) 
J.M. Rhodes, M.J. Vollinger, Composition of basaltic lavas sampled by phase-2 of the Hawaii Scientific Drilling Project: Geochemical stratigraphy and magma types. Geochem. Geophys. Geosyst. 5, Q03G13 (2004). doi:10.1029/2002GC000434

B. Sallé, J.-L. Lacour, E. Vors, P. Fichet, S. Maurice, D.A. Cremers, R.C. Wiens, Laser-induced breakdown spectroscopy for Mars surface analysis: Capabilities at stand-off distance and detection of chlorine and sulfur elements. Spectrochim. Acta B 59, 1413-1422 (2004)

F.C. Serbena, V.O. Soares, O. Peitl, H. Pinto, R. Muccillo, E.D. Zanotto, Internal residual stresses in sintered and commercial low expansion $\mathrm{Li}_{2} \mathrm{O}-\mathrm{Al}_{2} \mathrm{O}_{3}-\mathrm{SiO}_{2}$ glass-ceramics. J. Am. Ceram. Soc. 94, 1206-1214 (2011). doi:10.1111/j.1551-2916.2010.04220

P. Toulmin III, A.K. Baird, B.C. Clark, K. Keil, H.J. Rose Jr., R.P. Christian, P.H. Evans, W.C. Kelliher, Geochemical and mineralogical interpretations of the Viking inorganic chemical results. J. Geophys. Res. 82, 4625-4634 (1977)

D.T. Vaniman, S.J. Chipera, D.L. Bish, M.C. Duff, D.B. Hunter, Crystal chemistry of clay-Mn oxide associations in soils, fractures, and matrix of the Bandelier Tuff, Pajarito Mesa, New Mexico. Geochim. Cosmochim. Acta 66, 1349-1374 (2002)

R.C. Wiens et al., The ChemCam Instruments on the Mars Science Laboratory (MSL) rover: Body unit and combined system performance. Space Sci. Rev. (this issue) 